American University Washington College of Law

Digital Commons @ American University Washington College of Law

2010

Preserving a Political Bargain: The Political Economy of the NonInterventionist Challenge to Monopolization Enforcement

Jonathan Baker

Follow this and additional works at: https://digitalcommons.wcl.american.edu/facsch_lawrev

Part of the Antitrust and Trade Regulation Commons, Law and Economics Commons, and the President/Executive Department Commons 


\title{
PRESERVING A POLITICAL BARGAIN: THE POLITICAL ECONOMY OF THE NON-INTERVENTIONIST CHALLENGE TO MONOPOLIZATION ENFORCEMENT
}

\author{
JONATHAN B. BAKER*
}

The antitrust laws prohibit both collusion among rivals and exclusion of rivals, when such conduct harms competition. From an economic point of view, the competitive danger from each is similar. A collusive agreement among rivals involving price or output, ${ }^{1}$ for example, harms competition by reducing industry output and raising prices. Yet a dominant firm can reach the same end by restricting its rivals' access to key inputs or the market, ${ }^{2}$ thereby inducing or forcing its rivals to reduce output and raise price. ${ }^{3}$ Under such circumstances, the dominant firm can achieve lower industry output and higher industry prices by reducing its own output. Anticompetitive exclusion can thus be understood as creating an "involuntary" or coerced cartel. ${ }^{4}$

\footnotetext{
* Professor of Law, Washington College of Law, American University. The author is grateful to Stuart Benjamin, Jamie Boyle, Harry First, Andy Gavil, Al Klevorick, Christopher Leslie, Steve Salop, Jim Salzman, Mike Seidman, Phil Weiser, two anonymous referees, and participants in the law and economics seminars at Harvard and Stanford and the faculty workshop at New York University for helpful discussions and comments. This article was written before the author joined the Federal Communications Commission, at which he serves as Chief Economist, and does not purport to represent the views of that agency or any of its Commissioners.

${ }^{1}$ Collusive agreements could also involve other dimensions of competition, such as quality of products or service, investment in future competition, or the development of new and better products or cheaper methods of production.

${ }^{2}$ A dominant firm may exclude its rivals without necessarily forcing them to exit the market; it may simply discourage or prevent its rivals from expanding.

${ }^{3} \mathrm{~A}$ group of firms collectively accounting for a dominant position and acting in concert can similarly exercise market power by excluding rivals.

IJonathan B. Baker, Mavericks, Mergers, and Exclusion: Proving Coordinated Competitive Effects Under the Antitrust Laws, 77 N.Y.U. L. REv. 135, 189-90 (2002). For an influential survey of antitrust's prohibition against anticompetitive exclusion, highlighting how the law implements these economic ideas, see Thomas G. Krattenmaker \& Steven C. Salop, Anticompetitive Exclusion: Raising Rivals' Costs to Achieve Power over Price, 96 YALE L.J. 209
} 
Notwithstanding the underlying economic similarity between collusion and exclusion, ${ }^{5}$ the antitrust norms against cartel behavior (collusion) are broadly accepted, ${ }^{6}$ while the norms governing exclusion are disputed. Most notably, the antitrust prohibition against monopolization, Sherman Act Section 2, is contested terrain. ${ }^{7}$

An unusual public dispute between the two U.S. federal antitrust enforcement agencies, the Federal Trade Commission and the Antitrust Division of the Justice Department, illustrates the lack of consensus within the antitrust community over what counts as exclusionary conduct generally, and monopolization in particular. During 2006 and 2007, the FTC and the DOJ conducted joint hearings on how best to enforce Section $2,{ }^{8}$ but the two agencies could not agree on what they had learned..$^{9}$ A final report, published in September 2008, was issued only by the DOJ. ${ }^{10}$ The FTC chose not to join, and a majority of its Commissioners termed the DOJ report "a blueprint for radically weakened

(1986). See also Susan A. Creighton, D. Bruce Hoffman, Thomas G. Krattenmaker \& Ernest A. Nagata, Cheap Exclusion, 72 AnTitrust L.J. 975 (2005).

${ }^{5}$ Collusion and exclusion are also closely linked in a second way: a cartel may need to employ an exclusionary strategy to prevent entry that would undermine its ability to exercise market power.

6 See generally William E. Kovacic, The Modern Evolution of U.S. Competition Policy Enforcement Norms, 71 ANTITRust L.J. 377 (2003); Thomas B. Leary, The Essential Stability of Merger Policy in the United States, 70 AnTITRust L.J. 105 (2002). The collusion norm has not always been accepted in the United States. Appalachian Coals, Inc. v. United States, 288 U.S. 344 (1933) (allowing a crisis cartel among distressed coal producers). Appalachian Coals was effectively overruled in 1940. United States v. Socony-Vacuum Oil Co., 310 U.S. 150 (1940).

${ }^{7}$ The monopolization offense prohibits a firm with monopoly power (usually measured as controlling at least two-thirds of the sales or production capacity in a market) from obtaining or maintaining that power through improper exclusionary conduct, as distinguished from "growth or development as a consequence of a superior product, business acumen, or historic accident." United States v. Grinnell Corp., 384 U.S. 563, 570-71 (1966). Sherman Act Section 2 was the primary antitrust statute employed by the government in attacking the Standard Oil and Microsoft monopolies. Standard Oil Co. of N.J. v. United States, 221 U.S. 1 (1911); United States v. Microsoft Corp., 253 F.2d 34 (D.C. Cir. 2001). The statute also bars attempted monopolization and conspiracy to monopolize.

${ }^{8}$ See generally U.S. Dep't of Justice, Public Hearings on Single Firm Conduct and Antitrust Law, http://www.usdoj.gov/atr/public/hearings/single_firm/sfchearing.htm. My testimony is available at Federal Trade Comm'n and U.S. Dep't of Justice, Sherman Act Section 2 Joint Hearing, Understanding Single-Firm Behavior, Section 2 Policy Issues (May 1, 2007), http://www.usdoj.gov/atr/public/hearings/single_firm/docs/225232. htm.

${ }^{9}$ See William E. Kovacic, Modern U.S. Competition Law and the Treatment of Dominant Firms: Comments on the Department of Justice and Federal Trade Commission Proceedings Relating to Section 2 of the Sherman Act (Sept. 8, 2008), available at http:// www.ftc.gov/os/2008/09/080908section2stmtkovacic.pdf.

10 U.S. Dep't of Justice, Competition and Monopoly: Single-Firm Conduct under Section 2 of the Sherman Act (2008) [hereinafter DOJ Section 2 Report], available at http://www.usdoj.gov/atr/public/reports/236681.pdf. 
enforcement of Section 2 of the Sherman Act."11 Eight months later, after a new administration had taken office, the Justice Department withdrew the report ${ }^{12}$ and declared its intention to reinvigorate Section 2 enforcement. ${ }^{13}$ The passion in the debate is striking given that the government rarely brings monopolization cases. ${ }^{14}$

Controversy over the monopolization prohibition was also fostered by the Justice Department's high-profile lawsuit involving Microsoft, brought during the Clinton administration and settled in the first year of the George W. Bush administration. ${ }^{15}$ The merits of this case-and what it proves about the role of Sherman Act Section 2-continue to be debated by antitrust commentators. ${ }^{16}$ The prohibition against monopolization is also at issue in an ongoing controversy over the antitrust treatment of bundled rebates or discounts by dominant firms. ${ }^{17}$

In Part I, I discuss how during the first decade of the 21st century the controversy over monopolization standards appeared in three arenas, involving legal policy, economic policy, and politics. In each arena, the dispute mainly arose as criticism of traditional approaches by advocates of less intervention. I interpret the non-interventionist critique of monopolization standards through a political economy lens, as a potential challenge to an informal political bargain reached during the 1940s by

${ }^{11}$ Statement of Commissioners Harbour, Leibowitz and Rosch on the Issuance of the Section 2 Report by the Department of Justice (Sept. 8, 2008), available at http://www.ftc. gov/os/2008/09/080908section2stmt.pdf. The Commission had four members at the time, and the fourth, Chairman William E. Kovacic, did not take sides. Kovacic, supra note 9.

12 Press Release, U.S. Dep't of Justice, Justice Department Withdraws Report on Antitrust Monopoly Law (May 11, 2009), available at http://www.usdoj.gov/atr/public/press_ releases/2009/245710.pdf.

${ }^{13}$ Christine Varney, Assistant Att'y Gen., Antitrust Div., U.S. Dep't of Justice, Vigorous Antitrust Enforcement in this Challenging Era (May 12, 2009), available at http://www. usdoj.gov/atr/public/speeches/245777.htm.

${ }_{14}$ Since 1977, the average has been less than one case per agency each year. See Kovacic, Enforcement Norms, supra note 6, at 449 tbl. 4.

${ }^{15}$ The government's complaint was filed on May 18, 1998, and the settlement was submitted as a proposed final judgment on Nov. 2, 2001. These and other government filings are available at http://www.usdoj.gov/atr/cases/ms_index.htm\#settlement. For an overview, see generally A. Douglas Melamed \& Daniel L. Rubinfeld, U.S. v. Microsoft: Lessons Leamed and Issues Raised 287-310, in ANTTrRust Stories (Eleanor M. Fox \& Daniel A. Crane eds., 2007).

16 Compare Andrew I. Gavil \& Harky First, Microsoft and the Globalization of Antitrust Law: Competition Policy for the Twenty-First Century (forthcoming 2010) (largely supportive of the case) with William H. Page \& John E. Lopatka, The Microsoft Case: Antitrust, High Technology, and Consumer Welfare (2007) (generally critical of the case); see generally Symposium: Identifying Exclusionary Conduct Under Section 2, 73 Antitrust L.J. 311 (2006).

${ }^{17}$ The dispute is described infra Part I.A. 
which competition was adopted as national economic policy in preference to regulation or laissez-faire. That bargain was reformed during the 1980s, through antitrust's Chicago School revolution, but not overturned.

With a political bargain in mind, the past decade's controversies over monopolization standards can be evaluated using insights from the economic literature on the stability of cartels. From this perspective, as I discuss in Part II, the non-interventionist criticism is best viewed as a bid for reform of the competition policy bargain, though it can also be interpreted as part of a broader attack on the post-New Deal regulatory state. In Part III, I question whether the bid for reform of the monopolization rules will succeed.

\section{NON-INTERVENTIONIST CRITIQUES OF MONOPOLIZATION STANDARDS}

Judge Learned Hand's influential 1945 opinion upholding a government monopolization case against Alcoa emphasized a fear of false negatives-the possibility that antitrust law, by failing to identify violations, would produce a lethargic monopolist with little incentive to cut costs or innovate. ${ }^{18}$ Hand declined to interpret "exclusion" very narrowly "as limited to maneuvers not honestly industrial, but actuated solely by a desire to prevent competition," because to do so "would permit just such consolidations as [the Sherman Act] was designed to prevent."19 Consistent with this perspective, during the 1960 s through the early 1980 s, monopolization standards were placed under pressure primarily from antitrust progressives. Most notably, advocates of no-fault de-monopolization during those years saw Sherman Act enforcement as inadequate to address the problems created by dominant firms. ${ }^{20}$

In contrast with Judge Hand's vision, Robert Bork, a leading Chicago School commentator, expressed deep skepticism about exclusion as an antitrust theory, particularly as applied to dominant firm conduct. ${ }^{21}$ Fol-

\footnotetext{
18 United States v. Aluminum Co. of Am., 148 F.2d 416 (2d. Cir. 1945) (Alcoa). The Alcoa decision revitalized government enforcement of Section 2. ANDrEW I. GAviL, WIL. liam E. Kovacic \& Jonathan B. Baker, Antitrust l.aw in Perspective: Cases, Concepts and Problems in Competrtion Policy 616 (2d ed. 2008).

${ }^{19} \mathrm{Id}$. at 431 . The opinion also includes other language, often quoted, that can be interpreted as expressing concerns about the possibility of false positives. Id. at 430 ("The successful competitor, having been urged to compete, must not be turned upon when he wins.").

${ }^{20}$ See generally William E. Kovacic, Failed Expectations: The Troubled Past and Uncertain Future of the Sherman Act as a Tool for Deconcentration, 74 IOWA L. REV. 1105 (1989).

21 See, e.g., Robert H. Bork, The Antitrust Paradox 346 (1978) ("[W] here an efficiency potential appears in a case involving an individual refusal to deal, and there is no clear
} 
lowing Bork's lead, the primary criticism of monopolization standards and enforcement during the first decade of the 21st century has come from antitrust conservatives-those calling on courts and enforcers to cut back. ${ }^{22}$

These non-interventionist challenges can usefully be separated into legal policy arguments, economic policy arguments, and political arguments. ${ }^{23}$ Each has three salient features: it was seriously offered, it has met with opposition, and it has not (as yet) carried the day. In the courts, two of these critiques have made major inroads, ${ }^{24}$ but the third, the political critique, has been soundly rejected.

\section{A. The Legal Policy Critique ${ }^{25}$}

The modern distinction between the legal standards governing predatory pricing and those governing (non-price) exclusionary conduct has framed the recent legal policy critique of monopolization rules. In predatory pricing cases, the allegation is that a dominant firm has excluded a rival (or rivals) by cutting prices, thereby leading competing firms to back off from aggressive competition (as by raising prices) or exit the market entirely. Competition is harmed if the dominant firm obtains monopoly power, typically permitting it to raise prices above a competitive level, or maintains monopoly power, allowing it to preserve prices above competitive levels when prices otherwise would have eroded. In exclusionary conduct cases, by contrast, the dominant firm allegedly excludes rivals through other means, for example, by limiting or cutting off altogether competitors' access to key inputs or to the market.

evidence that the purpose of the refusal was predatory, courts should generally find the refusal lawful, both because of tie-breaker considerations and because predation by an individual refusal to deal will be very uncommon") (emphases added); see also id. at 156 (firms "may conceivably" predate by imposing higher distribution costs on their rivals, but this theory has both a limitation and a complication).

22 Perhaps in response to this criticism, contemporary "post-Chicago" antitrust commentary on exclusionary conduct takes a view located between Hand and Bork. E.g., Krattenmaker \& Salop, supra note 4, at 213-14.

23 These arenas are distinguished in part by where the challenge takes place. Economic arguments are raised in the first instance in policy-oriented communities, legal arguments are proffered primarily by legal commentators and before courts, and political arguments are raised mainly in a broader public discussion.

${ }^{24}$ Cf. Leah Brannon \& Douglas H. Ginsburg, Antitrust Decisions of the Supreme Court, 1967 to 2007, Competition Pol'y InT'L, Autumn, 2007, at 3 (arguing that the Supreme Court has been "methodically re-working antitrust doctrine" to align it with sound economic analysis, generally through supermajority or unanimous decisions).

${ }^{25}$ This section is in part the product of collaboration with the author's casebook coauthors, as reflected in GAviL. ET Al., supra note 18, ch. 6. 
During antitrust's structural era, from the 1940s through the mid$1970 \mathrm{~s},{ }^{26}$ antitrust law treated both predatory pricing and exclusionary conduct by dominant firms with comparable hostility. ${ }^{27}$ Courts commonly accepted the idea that dominant firms used a range of weapons, price cutting included, to drive out rivals. ${ }^{28}$

Yet the possibility of predatory pricing was strongly questioned by commentators. Many critics, particularly those associated with the Chicago School, ${ }^{29}$ considered the strategy irrational for a dominant firm. ${ }^{30}$ Price predation is only profitable, after all, if the predator can expect to recoup the losses it incurs by cutting price by charging monopoly prices once its rivals are driven out. The critics of predatory pricing enforcement argued that this strategy would be unlikely to profit the predator because those higher prices are uncertain-rivals may not exit, and new competition may arise even if they do-and because each dollar in later monopoly profits is less valuable than a dollar in the initial loss. Moreover, the critics emphasized, enforcement against predatory pricing is dangerous because it can chill legitimate, procompetitive price cutting.

Arguments like these persuaded courts to adopt two doctrinal rules that throw up barriers to predatory pricing claims. The first presumes

${ }^{26} \mathrm{~A}$ brief description of three antitrust eras-classical, structural, and Chicago School-is set forth in Jonathan B. Baker, A Preface to Post-Chicago Antitrust, in Post CHIcago Developments in Antitrust Analysis 60-75 (Roger van den Bergh, Roberto Pardolesi \& Antonio Cucinotta eds., 2002).

${ }^{27}$ See United States v. Aluminum Co. of Am., 148 F.2d 416 (2d Cir. 1945) (non-price exclusionary conduct); Utah Pie Co. v. Cont'l Baking Co., 386 U.S. 685 (1967) (predatory pricing).

28 The claim that Standard Oil had obtained market power through predatory pricing had been generally accepted since at least the polemical writing of Ida Tarbell. IDA M. Taribell, The History of The Standaro Oil Company (1904). Chicago School commentators questioned that theory, for example in John McGee, Predatory Price Cutting: The Standard Oil (N.J.) Case, 1 J.L. \& Econ. 137 (1958). Modern commentators tend to believe that Standard Oil achieved its monopoly power through non-price exclusionary conduct rather than through price predation. See, e.g., Elizabeth Granitz \& Benjamin Klein, Monopolization by "Raising Rivals' Costs": The Standard Oil Case, 39 J. L. \& Econ. 1 (1996).

29 The most strident critics of predatory pricing standards were associated with the Chicago School. See generally Jonathan B. Baker, Predatory Pricing After Brooke Group: An Economic Perspective, 62 AntrTrust L.J. 585 (1994). But the rules were also questioned by commentators associated with the Harvard School. Phillip A. Areeda \& Donald F. Turner, Predatory Pricing and Related Practices Under Section 2 of the Sherman Act, 88 HARv. L. REv. 697 (1975).

${ }^{30}$ The claim that predatory pricing is irrational has been questioned in modern commentary, influenced by modern economic analyses demonstrating how recoupment could in fact work. Baker, Predatory Pricing, supra note 29; Patrick Bolton, Joseph Brodley \& Michael H. Riordan, Predatory Pricing: Strategic Theory and Legal Policy, 88 Geo. L.J. 2239 (2000); Aaron Edlin, Predatory Pricing, in Research Handobook on the Economics of ANTITRUST LAW (Einer Elhauge ed., forthcoming). The changing economic views of predatory pricing are surveyed in GAVIL ET AL., supra note 18, at 675-80 (Sidebar 6-3). 
that a dominant firm's prices are not predatory if they are above some measure of that firm's costs-usually average variable cost. ${ }^{31}$ The second requires that a plaintiff alleging predatory pricing demonstrate that it would be profitable for the dominant firm to engage in a strategy of losing money initially; the plaintiff must do so by showing that the defendant would likely recoup those losses later..$^{32}$ These doctrinal rules, in combination with Supreme Court rhetoric questioning the rationality of price predation as a business strategy, have made predatory pricing cases extremely difficult for plaintiffs to win. ${ }^{33}$

By contrast, plaintiffs can more easily satisfy the rules applied to identify monopolization through non-price exclusionary conduct. Between the mid-1980s and the mid-1990s, when the Supreme Court was writing strong pro-defendant predatory pricing decisions in Matsushita ${ }^{34}$ and Brooke Group, ${ }^{35}$ the Court supported the plaintiffs in two exclusionary conduct cases, Aspen $^{36}$ and Kodak. ${ }^{37}$ More recently, two government victories in Sherman Act monopolization cases involving exclusionary conduct have been sustained on appeal. ${ }^{38}$

Aspen and the D.C. Circuit's en banc decision in Microsoft ${ }^{39}$ together establish a structured reasonableness analysis of dominant firm conduct. Under this approach, a court first examines the conduct's anticompetitive effects (as to which plaintiff bears a burden of production), then evaluates the monopolist's business justification (as to which defendant bears a burden of production), and, in a final step, balances the two (with the plaintiff bearing the ultimate burden of persuasion). ${ }^{40}$ This

\footnotetext{
${ }^{31}$ This standard was recommended in 1975 by Areeda and Turner, supra note 29, and was adopted by many courts. See generally ABA SECrion OF AnTITRUST LAw, ANTITRUST LAW DeVElopMents 274-81 (6th ed. 2007).

32 Brooke Group Ltd. v. Brown \& Williamson Tobacco Corp., 509 U.S. 209 (1993); Matsushita Elec. Indus. Corp. v. Zenith Radio Corp., 475 U.S. 574 (1986); Cargill Inc. v. Monfort of Colo., Inc., 479 U.S. 104 (1986).

${ }^{33}$ E.g., United States v. AMR Corp., 335 F.3d 1109 (10th Cir. 2003) (affirming summary judgment for defendant); but of. Spirit Airlines, Inc. v. Northwest Airlines, Inc., 431 F. $3 \mathrm{~d}$ 917 (6th Cir. 2005) (reversing summary judgment for defendant).

${ }^{34}$ Matsushita, 475 U.S. 574.

35 Brooke Group, 509 U.S. 209.

${ }^{36}$ Aspen Skiing Co. v. Aspen Highlands Skiing Corp., 472 U.S. 585 (1985).

${ }^{37}$ Eastman Kodak Co. v. Image Technical Servs., Inc., 504 U.S. 451 (1992).

38 United States v. Microsoft Corp., 253 F.3d 34 (D.C. Cir. 2001) (en banc); United States v. Dentsply Int'l, Inc., 399 F.3d 181 (3d Cir. 2005).

${ }^{39}$ Microsoft, 253 F.3d 34.

${ }^{40}$ Gavil ET AL., supra note 18, at 703. Cf. A. Douglas Melamed, Exclusive Dealing Arrangements and Other Exclusionary Conduct-Are There Unifying Principles? 73 ANTITRUST L.J. 375, 381 (2006) (a balancing test gives firms insufficient guidance on how to comply with the law without excessively forgoing aggressive competition). The balancing step is informed by the choice of welfare standard (whether antitrust is understood as maximizing con-
} 
test is easier to satisfy than the predatory pricing test, most importantly because it does not incorporate an initial safe harbor screen comparable to the price-cost comparison used in predatory pricing cases.

The more demanding judicial approach toward predatory pricing was seized on as a model by commentators who viewed the legal doctrine governing exclusionary conduct by monopolists as making it too easy to prove a violation. ${ }^{41}$ To raise the bar for plaintiffs, they proposed limiting judicial scrutiny of dominant firm behavior to conduct that sacrificed short-term profits; this approach would generalize the price-cost test to apply to non-price exclusionary conduct. ${ }^{42}$ Only if the dominant firm is sacrificing short-term profits, the argument goes, can courts be confident that the conduct is the product of a potentially anticompetitive exclusionary business strategy rather than procompetitive conduct. A variant of the profit-sacrifice proposal would limit the possibility of monopolization enforcement to exclusionary conduct that supposedly makes "no economic sense" absent an anticompetitive effect on prices or other dimensions of competition. ${ }^{43}$

sumer welfare or aggregate welfare). Steven C. Salop, Exclusionary Conduct, Effect on Consumers, and Flawed Profit-Sacrifice Standard, 73 ANTITRUST L.J. 311 (2006). For a survey of the welfare standard debate, see Jonathan B. Baker, Competition Policy as a Political Bargain, 73 Antitrust L.J. 483, 515-22 (2006).

${ }^{41}$ Professor Elhauge describes Robert Bork, both as scholar and judge, as having done the most to popularize a definition of "predatory" conduct that incorporates short-term sacrifice. Einer Elhauge, Defining Better Monopolization Standards, 56 Stan. L. Rev. 253, 269 (2003). Bork applied his definition to both price predation and non-price conduct, and expressed skepticism about the plausibility of such strategies unless they involved misuse of the courts or other agencies of government. BoRk, supra note 21, at 148-49. Some who wish to raise the bar to proving monopolization through non-price conduct also favor adopting a bright-line rule, such as the profit-sacrifice standard, on the ground that doing so would encourage procompetitive business activities by limiting uncertainty as to what conduct would be found unlawful. E.g., A. Douglas Melamed, Exclusionary Conduct Under the Antitrust Laus: Balancing, Sacrifice, and Refusals to Deal, 20 Berkeley TECH. L.J. 1247, 1257 (2005).

42 See DOJ SECTION 2 REPORT, supra note 10, at 39 (profit-sacrifice test draws on the Supreme Court's predatory pricing jurisprudence). Ordover and Willig laid the foundation for the early 21st century legal controversy nearly three decades ago, when they proposed applying the profit-sacrifice test to analyze behavior in concentrated markets protected by both entry barriers and reentry barriers, much as proof of monopoly power is required before applying the price-cost test in predatory pricing analysis. Janusz A. Ordover \& Robert D. Willig, An Economic Definition of Predation: Pricing and Product Innovation, 91 YALE L.J. 8 (1981). Further analysis would presumably be required to determine the competitive consequences of the conduct in the event the profit-sacrifice test was satisfied, much as occurs in price predation cases through application of the recoupment requirement. But if the initial screen is sufficiently stringent, the later analysis is less important for resolving cases.

${ }^{43}$ Melamed, supra note 40; Gregory J. Werden, Identifying Exclusionary Conduct Under Section 2: The "No Economic Sense" Test, 73 ANTrrrust L.J. 413 (2006). 
These proposals for toughening the standard for evaluating exclusionary conduct by dominant firms by adding a screening step to the analytical framework have been criticized as underinclusive, that is, as leading to false negatives and underdeterrence. ${ }^{44}$ The most important objection to the profit-sacrifice and no economic sense tests is that anticompetitive exclusion could readily be inexpensive for the dominant firm to undertake yet harmful to society ${ }^{45}$ Such anticompetitive conduct would be attractive to the dominant firm and difficult to rule out under the profit-sacrifice or no economic sense tests. A related objection is that these tests place the focus of the judicial inquiry on the dominant firm's intent when it belongs on anticompetitive effect.

These criticisms of the profit-sacrifice and no economic sense tests have reduced the interest in modifying standards for exclusionary conduct by dominant firms to parallel those governing predatory pricing. By the end of the first decade of the 21st century, advocates of tougher standards for proving monopolization based on non-price conduct increasingly favored two alternative approaches. The first would limit the definition of anticompetitive exclusionary conduct to actions that produce harms to competition disproportionate to the resulting benefitsa standard that would directly place a thumb on the scales in favor of monopolist defendants. ${ }^{46}$ The second approach would apply different rules to different types of exclusionary conduct, allowing courts to impose an elevated standard for plaintiffs when defendant conduct is considered largely benign and the risk of chilling procompetitive conduct the greatest, as with predatory pricing. ${ }^{47}$ The Justice Department's recent Section 2 report, for example, called on courts to follow both of these non-interventionist approaches, favoring the development of conduct-specific tests but preferring the disproportionate impact test when conduct-specific tests are not applicable. ${ }^{48}$

${ }^{44}$ See generally Andrew I. Gavil, Exclusionary Distribution Strategies by Dominant Firms: Striking a Better Balance, 72 ANritrust L.J. 3 (2004); Salop, supra note 40.

45 See generally Creighton et al., supra note 4.

46 See Gavil, supra note 44, at 61 (describing the test as "advocated" by the government and "attributed" to Professor Herbert Hovenkamp) (citing 3 Phillip Areeda \& Herbert Hovenkamp, ANTITRust Law II 651a, at 72 (2d ed. 2002)).

${ }^{47}$ Mark S. Popofsky, Defining Exclusionary Conduct: Section 2, The Rule of Reason, and the Unifying Principle Underlying Antitrust Rules, 73 ANTITRUST L.J. 435 (2006). This approach can be justified on decision-theoretic grounds and, in consequence, is a means of raising the bar of proving monopolization based on exclusionary conduct only if the terms of the rule are specified against the background of greater concern with false positives than false negatives.

48 DOJ SECTION 2 REPORT, supra note 10. As an amicus, the DOJ had previously encouraged the Supreme Court to adopt the disproportionality test. Brief for the United States \& the Federal Trade Commission as Amici Curiae Supporting Petitioner at 14, 
After this debate, it is unclear what standard the Supreme Court would apply to evaluate the propriety of exclusionary conduct by dominant firms. The structured reasonableness test described by the D.C. Circuit in its en banc decision in Microsoft, which recalls the analysis in Aspen, ${ }^{49}$ is an authoritative synthesis of Supreme Court precedent. But it is hard to know whether the Court would continue to follow that precedent in a new decision, as the Court has recently questioned its jurisprudence in this area. ${ }^{50}$

The differing legal treatment of price predation and other exclusionary conduct by monopolists has also, and not surprisingly, generated a prominent dispute over classification. ${ }^{51}$ The controversy involves the legal rule that should govern bundled rebates provided to retailers by dominant manufacturers. ${ }^{52}$ The issue was framed by LePage's, an appellate decision in 2003 that sustained a district court's treble damage award of nearly $\$ 70$ million to an excluded rival of a dominant firm. ${ }^{53}$ The dominant manufacturer argued that even if it were viewed as a monopolist in one of its product lines, its rebates could not be predatory because they did not reduce the price of the monopolized good below cost. $^{54}$ The appellate court declined to judge the conduct using the predatory pricing-like standard proposed by the dominant manufacturer. The court instead sustained the district court's verdict based on its conclusion that the bundled rebates excluded a rival manufacturer, resulting in higher prices to buyers, with no procompetitive justification.

The decision in LePage's set off a legal controversy over monopolization standards because exclusion arising from bundled rebates or discounts resembles both price predation and exclusionary conduct. It

Verizon Commc'ns Inc. v. Law Offices of Curtis V. Trinko, LLP, 540 U.S. 398 (2004) (No. 02-682) (sec. III.D), available at http://www.usdoj.gov/atr/cases/f201000/201048.htm.

${ }^{49}$ The Microsoft decision relies on Aspen, but cites it only once. United States v. Microsoft Corp., 253 F.3d 34, 59 (D.C. Cir. 2001).

50 Trinko, 540 U.S. at 409 ("Aspen Skiing is at or near the outer boundary of Section 2 liability”); Pacific Bell Tel. Co. v. linkLine Commc'ns, Inc., 129 S. Ct. 1109, 1118 (2008) (Aspen suggests that a firm's unilateral refusal to deal with its rivals can give rise to antitrust liability in "limited circumstances"). Appeals courts have followed Trinko and linkLine in reading Aspen narrowly. Broadcom Corp. v. Qualcomm Inc., 501 F.3d 297, 316 (3d Cir. 2007); MetroNet Services Corp. v. Qwest Corp., 383 F.3d 1124, 1131-34 (9th Cir. 2004).

51 For a general discussion of problems of classification in antitrust jurisprudence, see Mark A. Lemley \& Christopher R. Leslie, Categorical Analysis in Antitrust Jurisprudence, 93 lowA L. REv. 1207 (2008).

${ }^{52}$ Bundled rebates are based on aggregating the retailer's purchases of multiple goods produced by the manufacturer.

${ }^{53}$ LePage's Inc. v. 3M, 324 F.3d 141 (3d Gir. 2003).

${ }^{54}$ That is, the manufacturer claimed that the price of the monopolized product, one product in the bundle, would not be below cost even if the entire rebate were attributed to it. 
looks like price predation because the manufacturer cuts price for the bundle, but it looks like exclusionary conduct (whether characterized as foreclosure, raising rivals' costs, or tying) when the price cut is spread over multiple products, the discount schedule varies with the amount purchased, the dominant firm increases the unbundled price coincident with offering the discount, or the discount is conditioned on the purchase of a bundle of products. Other courts have applied different tests to evaluate bundled discounts than the test adopted in Le Page's, ${ }^{55}$ and the legal rules that apply to bundled discounts are not settled. ${ }^{56}$

The classification dispute over bundled rebates provided to retailers by dominant manufacturers involves more than a technical argument about the economic effects of a particular practice. It is also, in part, a proxy battle over the legal standard that should govern non-price exclusionary conduct by monopolists, fostered by non-interventionist skepticism about the value of antitrust enforcement against exclusionary conduct by dominant firms more generally. That broad skepticism, in turn, relies upon a number of economic policy arguments.

${ }^{55}$ Cascade Health Solutions v. PeaceHealth, 515 F.3d 883 (9th Cir. 2008); Ortho Diagnostic Sys., Inc. v. Abbott Labs., Inc., 920 F. Supp. 455 (S.D.N.Y. 1996). The Antitrust Modernization Commission also recommended a test for evaluating bundled rebates. ANtitrust Modervization Comm'n, Report and Recommendations 99 (2007) [hereinafter AMC REPORT], available at http://govinfo.library.unt.edu/amc/report_recommenda tion/toc.htm. The Justice Department proposed yet another approach in the Section 2 report (DOJ SECTION 2 REPORT, supra note 10, at 91-117), which the FTC majority criticized. Statement of Commissioners Harbour et al., supra note 11, at 7-8. For a description and critical survey of the approaches adopted by the AMC and various courts, see Erik Hovenkamp \& Herbert Hovenkamp, Exclusionary Bundled Discounts and the Antitrust Modernization Commission, 53 Antitrust Bull. 517 (2008). For an economic analysis of the practice, see Patrick Greenlee, David Reitman \& David S. Sibley, An Antitrust Analysis of Bundled Loyalty Discounts, 26 INT'L J. Indus. ORG. 1132 (2008).

${ }^{56}$ The treatment of refusals to deal is also hotly debated, but that debate extends beyond monopolization to also include vertical agreements, vertical mergers, exclusionary group boycotts, and tying and exclusive dealing under Clayton Act Section 3. In the monopolization context, the argument revolves around unilateral refusals to deal with competitors. The Justice Department's Section 2 report argued that unconditional and unilateral refusals to deal with rivals should "not play a meaningful part in section 2 enforcement," DOJ SECrion 2 REPORT, supra note 10, at 127, 129, as suggested by Trinko, 540 U.S. at 408 ("[e]nforced sharing also requires antitrust courts to act as central planners, identifying the proper price, quantity, and other terms of dealing - a role for which they are ill-suited"). Professor Salop responded that setting terms of dealing requires nothing more than determination of the monopolist's price and cost-a task that the Supreme Court has encouraged courts to undertake when applying a price-cost screen in predatory pricing cases. Steven C. Salop, Refusals to Deal and Price Squeezes by an Unregulated, Vertically Integrated Monopolist, infra this issue, 76 ANTITrust L.J. 709 (2010). 


\section{B. The Economic Policy Arguments}

The non-interventionist challenge to the rules governing monopolization through non-price exclusionary conduct is grounded in economics. ${ }^{57} \mathrm{It}$ is based on at least six economic policy arguments, some framed decades ago by Chicago School scholars challenging various aspects of structural era antitrust enforcement. ${ }^{58}$ Collectively, these economic arguments against monopolization enforcement contend that the cure is worse than the disease.

(1) Markets are self-correcting. Monopolization is not a serious problem because markets are generally self-correcting. That is, the exercise of monopoly power will predictably erode over time through entry or fringe expansion or, in high-tech markets, through leapfrog innovation. ${ }^{59}$ Hence false positives are more common and more costly than false negatives. ${ }^{60}$

(2) Monopoly fosters economic growth. Monopoly is good, and monopolization enforcement counterproductive because the anticipated opportunity to charge a monopoly price induces the innovation and investment that lead to economic growth. ${ }^{61}$ Monopolization enforcement chills procompetitive innovation and investment by current and would-be dominant firms throughout the economy, even in industries not directly involved in monopolization cases.

(3) There is only a "single monopoly profit." A monopolist has already obtained its monopoly profit, so cannot make matters worse through conduct involving sellers of complementary products that is often treated as suspect, e.g., by competing in related markets (sometimes

\footnotetext{
57 Predatory pricing is also the subject of economic debate. For criticism of the leading court precedents in this area as too non-interventionist, see the sources cited supra note 30.

${ }^{58}$ On the transition from antitrust's structural era to its Chicago School era, see generally Baker, A Preface to Post-Chicago Antitrust, supra note 26, at 63-67.

${ }^{59}$ E.g., Fred S. McChesney, Talkin' 'Bout My Antitrust Generation: Competition for and in the Field of Competition Law, 52 EмоRY L.J. 1401, 1412 (2003). On high-tech markets, see, for example, Christopher Pleatsikas \& David Teece, The Analysis of Market Definition and Market Power in the Context of Rapid Innovation, 19 INr'L J. Indus. ORG. 665 (2001).

${ }^{60}$ Frank Easterbrook, The Limits of Antitrust, 63 Tex. L. Rev. 1, 15 (1984) ("[I]n many cases the costs of monopoly wrongly permitted are small, while the costs of competition wrongly condemned are large.").

${ }^{61}$ E.g., David S. Evans \& Keith N. Hylton, The Lawuful Acquisition and Exercise of Monopoly Power and Its Implications for the Objectives of Antitrust, CompetiTion Pol'y INT'L, Autumn 2008, at 203.
} 
termed "monopoly leveraging"), tying, vertically integrating upstream or downstream, or selecting an exclusive distributor or exclusive supplier. ${ }^{62}$

(4) Excluded fringe rivals may not matter competitively. The exclusion of horizontal rivals to a dominant firm may not matter to market performance. Excluded fringe rivals are often small because they are inefficient, high-cost producers. ${ }^{63}$

(5) Courts cannot reliably identify monopolization, or effectively remedy or regulate it. Antitrust enforcement is not well-suited for improving market outcomes because of the limited institutional capability of courts. ${ }^{64}$ Judges and juries cannot reliably identify harmful exclusionary conduct by a monopolist because of the difficulty disentangling the benefits to competition from the harms when the efficiencies arise in the same market where market power is alleged. ${ }^{65}$ Nor can judges easily devise remedies for monopolization, even when a problem is uncovered, particularly when slow-moving courts are asked to deal with fast-moving high-tech markets. ${ }^{66}$ Not surprisingly, the history of monopolization enforcement is littered with misguided lawsuits and ineffective or counterproductive remedial decrees. ${ }^{67}$

(6) The prohibition on monopolization is subject to misuse. Much monopolization litigation, government cases included, is instigated by unsuccessful and inefficient rivals. Those firms, having lost out in the marketplace, seek to reverse that misfortune in the courts, either as plaintiffs or as instigators of enforcement agency lawsuits, through trumped up claims of exclusion. ${ }^{68}$ Even successful rivals may bring unwarranted exclusion claims, moreover, in order to discourage the dominant firm from engaging in hard competition.

${ }^{62}$ E.g., Bork, supra note 21, at 372-75; Aaron Director \& Edward H. Levi, Law and the Future: Trade Regulation, 51 Nw. U. L. Rev. 281, 290-91 (1956); Richard Posner, The Chicago School of Antitrust Analysis, 127 U. PA. L. REV. 925, 925-27 (1979).

${ }^{63}$ See, e.g., DOJ SEction 2 REPORT, supra note 10, at $100 \mathrm{n} .100$ (citing 3 Phillip E. Areeda \& Herbert Hovenkamp, ANTITRust LAw I 749a, at 242, I 749b1, at 249 (Supp. 2007) as making this argument).

${ }^{64}$ See Easterbrook, supra note 60, at 15 ("the economic system corrects monopoly more readily than it corrects judicial errors"); Thomas O. Barnett, Section 2 Remedies: What to Do After Catching the Tiger by the Tail, 76 AnTITRUsT L.J. 31 (2009).

${ }_{65}$ See Frank H. Easterbrook, On Identifying Exclusionary Conduct, 61 Notre Dame L. Rev. 972, 972 (1986) ("Competitive and exclusionary conduct [by a monopolist] look alike."); Bork, supra note 21 , at 344 .

66 See, e.g., William J. Baumol, Robert E. Litan \& Carl. J. Schramm, Good Capitalism, Bad Capitalism, and the Economics of Growth and Prosperity 8-19 (2007).

${ }^{67}$ E.g., BORK, supra note 21, at 181-82 (discussing cases against United Shoe Machinery and IBM); Robert W. Crandall, The Failure of Structural Remedies in Sherman Act Monopolization Cases, 80 Or. L. Rev. 109 (2001).

68 See Easterbrook, supra note 60, at 33-38. 
These arguments vary in their emphasis. The first four suggest that monopolies are not very harmful (or are even, according to the second argument, beneficial). The last two suggest that even if monopoly were harmful, monopolization enforcement is unlikely to improve social welfare. ${ }^{69}$

These anti-enforcement arguments have received a serious reception. Several courts have relied upon the "single monopoly profit" claim in the context of analyzing vertical agreements, ${ }^{70}$ and the Supreme Court, in the 2004 Trinko monopolization decision, arguably offered three others. ${ }^{71}$ These arguments have also received a serious reception at the Department of Justice. ${ }^{72}$

Yet they are controversial. Each has drawn a rebuttal in commentary, and other courts ignore or reject them. ${ }^{73}$ Six counter-arguments, set forth below, respond to the six economic arguments for the non-interventionist position. Together the counter-arguments suggest that monopolies are harmful and that monopolization enforcement is likely to benefit society.

${ }^{69}$ These arguments differ in one respect from those historically deployed by Chicago School critics of structuralera rules governing vertical agreements (which, in part, also targeted exclusionary conduct): the argument that vertical contracts benefit competition (e.g., by helping firms align incentives to prevent free riding and holdups) is not close to the claim that monopoly fosters economic growth. On the other hand, the administrability arguments proffered by critics of the old rules governing vertical restraints (that courts cannot easily craft a remedy and that judicial processes are too attentive to complaints from inefficient rivals) are similar to the last two economic arguments against traditional monopolization doctrine, and the single monopoly profit argument is made in both settings.

${ }^{70}$ E.g., G.K.A. Beverage Corp. v. Honickman, 55 F.3d 762, 767 (2d Cir. 1995); Town of Concord v. Boston Edison Co., 915 F.2d 17, 23, 32 (1st Cir. 1990) (Breyer, C.J.); see Jefferson Parish Hosp. Dist. No. 2 v. Hyde, 466 U.S. 2, 36-37 (1984) (O'Connor, J., concurring).

${ }^{71}$ Verizon Commc'ns Inc. v. Law Offices of Curtis V. Trinko, LLP, 540 U.S. 398 (2004). Justice Scalia's majority opinion can be read to claim that monopolies are temporary (hence self-correcting), and that they foster economic growth (as the prospect of monopoly induces risk taking and innovation). Id. at 406. The opinion also highlights the risk of false positives from Section 2 enforcement and, at least with respect to the violation alleged in the case, the difficulty of crafting relief to avoid ongoing judicial supervision (both suggesting that courts cannot successfully address monopolization claims). Id. at 407-08, 414-15.

${ }^{72}$ E.g., Thomas O. Barnett, Assistant Att'y Gen., Antitrust Div., U.S. Dep't of Justice, Competition Enforcement in an Innovative Economy (June 20, 2008), available at http:// www.usdoj.gov/atr/public/speeches/234246.htm.

73 Prominent monopolization decisions since 2000 expressly or implicitly rejecting these arguments include United States v. Dentsply Int'l, Inc., 399 F.3d 181 (3d Cir. 2005); LePage's Inc. v. 3M, 324 F.3d 141 (3d Cir. 2003); United States v. Microsoft, 253 F.3d 34 (D.C. Cir. 2001). 
(1) Monopoly power is often durable. Some markets may self-correct, but economic theory suggests many reasons why monopoly power would not be transitory, ${ }^{74}$ and the case law offers examples of durable market power, ${ }^{75}$ including in high-tech markets. ${ }^{76}$ Accordingly, anticompetitive monopolization is a serious concern.

(2) Competition, not monopoly, fosters economic growth. The empirical evidence demonstrates that market power is typically bad for innovation: the push of competition generally spurs innovation and investment more than the pull of monopoly. "Dynamic competition" is no excuse for allowing monopolization. ${ }^{78}$

(3) Dominant firms can often extend their market power through exclusionary conduct. The single monopoly profit argument holds only under narrow conditions. More commonly, a dominant firm can exercise additional power through exclusionary conduct that raises costs facing fringe rivals, sellers of more distant substitutes, or potential entrants, or that limits the access of those firms to customers. ${ }^{79}$

(4) Competition between a dominant firm and inefficient rivals can be beneficial. Any rival, even an inefficient one, can constrain a dominant firm's prices to some extent, limiting the dominant firm's exercise of monopoly power. ${ }^{80}$ Even a small and inefficient rival, moreover, can potentially

\footnotetext{
${ }^{74}$ See, e.g., Ariel Ezrachi \& David Gilo, Are Excessive Prices Really Self-Correcting?, 5 J. ComPETITION L. \& ECON. 249 (2008) (supracompetitive prices only attract entry efforts if they -signal that the post-entry price would be high or that the incumbent firms have high costs, and even then entry may not succeed in competing those prices down to competitive levels). Indeed, exclusionary conduct by monopolists may erect entry barriers.

${ }^{75}$ E.g., United States v. Standard Oil Co., 221 U.S. 1 (1911); United States v. Dentsply Int'l, Inc., 399 F.3d 181 (3d Cir. 2005).

${ }^{76}$ United States v. Microsoft Corp., 253 F.3d 34 (D.C. Cir. 2001).

${ }^{77}$ Jonathan B. Baker, Beyond Schumpeter vs. Arrow: How Antitrust Fosters Innovation, 74 ANTITRust L.J. 575, 583-86 (2007). Moreover, exclusionary conduct by dominant firms may be directed particularly at innovative rivals.

${ }^{78}$ Jonathan B. Baker, "Dynamic Competition" Does Not Excuse Monopolization, COMPETITION PoL'y INT'L, Autumn 2008, at 243. Cf. Catalano, Inc. v. Target Sales, Inc., 446 U.S. 643, 649 (1980) (rejecting the argument that the potential for supracompetitive prices to induce entry could justify horizontal price fixing).

${ }^{79}$ See generally Krattenmaker \& Salop, supra note 4; GAVIL ET AL., supra note 18, at 397-98, 417-18, 811-12, 861-65. Cf. Einer Elhauge, Tying, Bundled Discounts, and the Death of the Single Monopoly Profit Theory, 123 Harv. L. REv. 397 (2009) (questioning application of the "single monopoly profit" argument in the tying context).

${ }^{80}$ See DOJ Section 2 Report, supra note 10, at 100 n.100 (citing Professors Elhauge and Salop as making this argument). This point is also evident in the familiar model of a dominant firm and competitive fringe.
} 
grow to challenge a dominant firm in the future, and it may have a leg up on a de novo entrant in doing so. ${ }^{81}$

(5) Monopolization cases do not present unique remedial problems. The difficulties courts face in identifying and remedying anticompetitive conduct in monopolization cases are no more serious than those arising in other settings, like mergers or anticompetitive agreements that are evaluated under a reasonableness standard.$^{82}$ Many monopolization cases have involved exclusionary conduct by a dominant firm with no serious efficiency justification-a setting in which the harm to competition is not confounded by procompetitive benefits. ${ }^{83}$ Moreover, it makes little sense to make judgments about the deterrent effect of present-day enforcement by reviewing the theories and remedies employed in earlier eras, when legal standards and remedial approaches differed..$^{84}$

(6) Courts and enforcers are not routinely "captured" by rivals of dominant firms. The claim that agencies and courts dance to the tune of rivals assumes, implausibly, that less successful firms are better able to manipulate governmental processes than successful dominant firms, and is in any case tantamount to supposing, without justification, that enforcers bring cases and courts decide them based on the identities of the parties rather than a review of the evidence. Moreover, it is no more difficult for enforcers and courts to discount testimony for possible biases when hearing from rivals as when hearing from dominant firms and customers-and all these sources of industry information can be helpful.

These counter-arguments present a strong rejoinder to the economic policy arguments against monopolization enforcement. The arguments against enforcement nevertheless offer a legitimate critique, and they have provided an economic underpinning for non-interventionist arguments made in the legal and political arenas.

\footnotetext{
${ }^{81}$ See Gavil, supra note 44, at 35, 36 (an inefficient rival might be targeted for exclusion by a dominant firm because the rival has the chance to become a more effective competitor, threatening the dominant firm's market power).

${ }^{82}$ Nor are the difficulties more severe than those courts may face in applying the balancing standards of negligence law to business conduct.

${ }^{83}$ E.g., Lorain Journal v. United States, 342 U.S. 143 (1951); see generally Creighton et al., supra note 4.

${ }^{84}$ For example, the FTC's monopolization case against Xerox did "a world of good" even if the firm had not engaged in bad acts sufficient to support a monopolization claim by modern standards. See Willard K. Tom, The 1975 Xerox Consent Decree: Ancient Artifacts and Current Tensions, 68 ANTrTrust L.J. 967 (2001). And the Justice Department's famous monopolization case against Standard Oil addressed a genuine competitive problem, even if a modern court would have chosen a different remedy. See Granitz \& Klein, supra note 28.
} 


\section{The Political Critique}

The modern political challenge to traditional monopolization standards arose in reaction to the government's monopolization case against Microsoft. Microsoft ran afoul of antitrust enforcers because of its response to what the company's leader, Bill Gates, termed the "Internet Tidal Wave." ${ }^{85}$ At the start of the Internet era, Microsoft's Windows software held a dominant position in operating systems for personal computers. In 1998, the Clinton administration charged that Microsoft's practices in marketing and designing its Internet browser harmed competition by thwarting a nascent challenge to Microsoft's Windows monopoly, with no other legitimate business purpose. ${ }^{86}$

During the trial, the company offered both a legal defense and a separate public relations defense. Microsoft's legal defense centered around its view that the operating system market was competitive, and that the company's 90 percent market share would erode rapidly if a rival introduced a better operating system, notwithstanding the initial dearth of compatible applications software..$^{87}$

Outside the courtroom, the firm went farther, questioning antitrust itself. In its public relations efforts, Microsoft described the government's monopolization case as an attack on its core business freedom to develop new technology and distribute it broadly to consumers. Microsoft claimed specifically that the litigation threatened the company's "freedom to innovate," 88 as if to claim it had a right to do as it pleases, particularly with respect to the use of its intellectual property, letting the competition chips fall as they may. ${ }^{89}$ In addition, Microsoft depicted the Justice Department as the pawn of its rivals, which, it said, had turned to the government for help when they were unable to suc-

${ }^{85}$ Bill Gates, The Internet Tidal Wave (May 26, 1995), available at http://www.usdoj. gov/atr/cases/exhibits/20.pdf.

86 See generally Melamed \& Rubinfeld, supra note 15.

87 See, e.g., Direct Testimony of Richard L. Schmalensee, United States v. Microsoft (Jan. 11, 1999) (economic expert for Microsoft), as reprinted in GAVIL ET AL., supra note 18, at 953-64.

${ }_{88}$ Ads in Newspapers Take Microsoft's Case to Its Users, SEATtLe Times, Apr. 9, 1998, http:// community.seattletimes.nwsource.com/archive $/$ ?date $=19980409 \& \mathrm{cslug}=2744284$. Microsoft's "Freedom to Innovate Network" still has an online presence, at http://www. microsoft.com/freedomtoinnovate/default.aspx.

${ }^{89}$ In a nod toward this political argument, Microsoft claimed in the court case that any exclusionary conduct that took the form of restrictions on software licensing were legally justified because the company was simply exercising its rights as the holder of valid copyrights. See United States v. Microsoft, 253 F.3d 34, 63 (D.C. Cir. 2001) (rejecting this argument). 
ceed in the market ${ }^{90}$ Microsoft also lobbied Congress to cut the Justice Department's antitrust enforcement budget. ${ }^{91}$

Through these steps, Microsoft provoked a high-profile public challenge to the legitimacy of antitrust and antitrust institutions ${ }^{92}$ Microsoft charged that antitrust undermines economic rights and facilitates inefficient rent seeking by rivals and it questioned whether the antitrust laws should ever govern firm behavior in high-tech markets.

Microsoft's challenge gained political traction during the 2000 presidential election campaign between Bush and Gore. In the midst of the campaign, the federal district court judge hearing the case found that Microsoft had violated the antitrust laws and, at the Clinton administration's request, ordered that the firm be broken in two. ${ }^{93}$ The Republican presidential candidate, George W. Bush, signaled his opposition and perhaps his sympathy for Microsoft's "freedom to innovate" argument. At a campaign appearance in Washington State, Microsoft's home, Bush expressed concern "if this company were to be broken apart, this engine of change, engine of growth [... . ]"94 Senator Slade Gorton, the Washington State Republican running a close but ultimately losing race for re-election, signaled that if Bush were elected, the case would be resolved favorably to Microsoft. ${ }^{95}$

The breakup order was placed on hold while the D.C. Circuit reviewed the case. In recognition of the importance of the case, and to forestall an expedited direct appeal to the Supreme Court, Microsoft's appeal was considered, unusually, by the D.C. Circuit sitting en banc. ${ }^{96}$

\footnotetext{
${ }^{90}$ E.g., A Case of Trial in Error: The Microsoft Antitrust Lawsuit (Dec. 7, 1998), http:// www.microsoft.com/presspass/features/1998/12-7trialdoc.mspx.

${ }^{91}$ Dan Morgan \& Juliet Eilperin, Microsoft Targets Funding for Antitrust Office, WasH. Post, Oct. 15, 1999, at Al, reprinted at http://articles.latimes.com/1999/oct/15/business/fi-22481.

${ }^{92}$ The monopolization litigation involving Microsoft captured the interest of the public in a way that few antitrust cases ever do. For perhaps only the second time in history, the U.S. government asked a court to break up a leading firm in a rapidly growing, cuttingedge industry run by the wealthiest person in the world. The other decision involved Standard Oil, controlled by John D. Rockefeller. United States v. Standard Oil Co., 221 U.S. 1 (1911).

${ }^{93}$ Melamed \& Rubinfeld, supra note 15, at 293.

${ }^{94}$ Mike Allen, Bush Hints He Would Not Have Prosecuted Microsoft, Wash. Post, Feb. 28, 2000, http://www.washingtonpost.com/wp-srv/pmextra/feb00/28/A43853-2000Feb28. html.

95 See John Hendren, Microsoft, Employees Throw Support to Gorton, SeATtLe Times, Nov. 5, 2000, http://community.seattletimes.nwsource.com/archive/?date $=20001105 \&$ slug=TTG 027QA2; cf. Donald Lambro, Bush Camp Sees Him Saving Microsoft, WASH. Times, Apr. 10, 2000 , at A4.

${ }^{96}$ See John Hendren, Appeals Count Ready to Hear Microsoft, SeAtTle Times, June 14, 2000, http:// community.seattletimes.nwsource.com/archive/?date $=20000614 \&$ slug $=4026564$.
} 
The most important vote on the appeals court was likely that of Judge Douglas Ginsburg. ${ }^{97}$ Ginsburg is both an antitrust expert and a regulation skeptic. ${ }^{98}$ If the courts were going to mount a broad non-interventionist challenge to antitrust enforcement, Judge Ginsburg was the obvious intellectual leader to frame the critique. Judge Ginsburg instead became competition's champion. His decision not to dissent plausibly allowed the case to be decided unanimously rather than by a narrow majority, heading off Microsoft's efforts to use this high-profile litigation to undermine the legitimacy of antitrust enforcement.

It is possible to imagine a counterfactual opinion-perhaps a majority opinion or perhaps a dissent-sympathetic to Microsoft's "freedom to innovate" argument. The opinion would have restated the six non-interventionist economic policy arguments, adapting them to a high-tech context. It would have claimed that antitrust law has evolved to address a concern for chilling innovation, particularly by exempting the application of antitrust rules to the development of new products. ${ }^{99}$ Based upon

\footnotetext{
${ }^{97}$ Ginsburg may be best known today for his unsuccessful Supreme Court nomination. He was credited with coining the phrase "Constitution in exile" to capture the nostalgia on the right for the way the Supreme Court enshrined economic rights a century ago, although a conservative commentator, Randy Barnett, denies that there is a constitution in exile" movement. See generally Debate Club, Legal Affars, May 2, 2005, http://www. legalaffairs.org/webexclusive/debateclub_cie0505.msp. Cf. Douglas H. Ginsburg, On Constitutionalism, 2002-2003 CATO SuP. CT. REv. 7 (2003), http://www.cato.org/pubs/scr/ 2003/constitutional.pdf (criticizing New Deal-era decisions of the Supreme Court for lack of fidelity to the written Constitution).

${ }_{98}$ Ginsburg served as Assistant Attorney General for Antitrust during the Reagan administration. Although he tends to be skeptical of government challenges to exclusionary conduct, he supports antitrust challenges to price-fixing cartels and to horizontal mergers that create highly concentrated markets. See, e.g., Douglas H. Ginsburg, Antitrust as An timonopoly, 14 ReGULATION 91, 100 (1991), available at http://www.cato.org/pubs/regulation/regv14n3/v14n3-9.pdf. On the D.C. Circuit, he wrote an antitrust opinion upholding an FTC decision challenging an agreement among rivals to divide markets. PolyGram Holding, Inc. v. FTC, 416 F.3d 29 (D.C. Cir. 2005). Another antitrust expert on the circuit court, Merrick Garland, did not participate in the en banc review, presumably because of his earlier service at the Justice Department.

${ }^{99}$ For support, the hypothetical opinion could have relied upon a Supreme Court decision affirming a lower court decision that exempted developing industries from the traditional per se prohibition against tying in order to allow new firms to develop a reputation for quality-United States v. Jerrold Electronics Corp., 187 F. Supp. 545 (E.D. Pa. 1960), affd per curiam, 365 U.S. 567 (1961); a Court decision holding that price fixing is not illegal per se when the agreement allowed them to create a new product-Broadcast Music, Inc. $v$. Columbia Broadcasting System, Inc., 441 U.S. 1 (1979); and a series of appellate decisions arguably establishing that the introduction of a new product cannot be the basis for a Section 2 violation unless the new product offers no benefit to buyers and instead purely operates to raise compatibility problems for rivals-Berkey Photo, Inc. v. Eastman Kodak Co. 603 F.2d 263 (2d Cir. 1979); Transamerica Computer Corp. v. IBM, 698 F.2d 1377 (9th Cir. 1963); Nontheastern Telephone Co. v. ATE'T Co., 651 F.2d 76 (2d Cir. 1981). The hypothetical opinion might also have cited the routine acceptance by the antitrust enforcement agencies of the development of better and cheaper products as a justification for what
} 
these economic and legal observations, the opinion would have concluded that antitrust law strongly presumes that competition and consumers benefit from unilateral conduct or vertical agreements entered into by firms in rapidly changing high-tech markets. It would have found for defendant Microsoft by applying this presumption to evaluate the specific claims of anticompetitive tying, exclusive dealing, and monopolization at issue in the case.

If this analysis had been at the core of the majority opinion in the D.C. Circuit, the Supreme Court that later decided Trinko ${ }^{100}$ may well have affirmed it. The result would have been to establish the principle that the antitrust laws do not apply in cutting-edge industries beyond the prohibition against horizontal collusion and perhaps the bar on anticompetitive horizontal mergers. Such an outcome would have taken a large step down the road toward abolishing concern with exclusionary conduct from the antitrust laws altogether.

In the actual case, the appellate decision, handed down in mid-2001, was unanimous and nothing like the hypothetical opinion sketched above. ${ }^{101}$ Doctrinally, the D.C. Circuit employed a structured reasonableness standard consistent with traditional monopolization precedents. ${ }^{102}$ Applying this test, the court agreed that Microsoft had acted improperly to maintain its dominant position in operating systems software by engaging in the marketing practices challenged by the government. ${ }^{103} \mathrm{But}$ the court rejected some peripheral monopolization violations identified by the trial court and sent the case back to the district court to reconsider the remedy.

Within the four corners of the legal dispute, both sides could claim a victory. On the one hand, the appeals court strongly affirmed the Justice Department's pursuit of the case. On the other hand, Microsoft bene-

\footnotetext{
might otherwise be an anticompetitive merger or joint venture. U.S. Dep't of Justice \& Fed. Trade Comm'n, Commentary on the Horizontal Merger Guidelines $\$ 4$ (2006), available at http://www.usdoj.gov/atr/public/guidelines/215247.htm.

100 Verizon Commc'ns Inc. v. Law Offices of Curtis V. Trinko, LLP, 540 U.S. 398 (2004).

${ }^{101}$ United States v. Microsoft Corp., 253 F.3d 34 (D.C. Cir. 2001).

102 See supra text at note 39. Although commentators advocating the "no economic sense" test treat the Microsoft decision as offering support for their views, the decision is better understood as setting forth a structured reasonableness test for Sherman Act Section 2 analogous to the approach applied under Section 1. This is evident in a comparison of the Microsoft decision with another decision of the same court, Polygram Holding, Inc. v. Federal Trade Commission, 416 F.3d 29 (D.C. Cir. 2005). See Gavil ET AL., supra note 18, at 202-11 (Sidebar 2-5) (discussing how the rule of reason has been structured in agreement cases).

${ }^{103}$ The court dismissed Microsoft's primary copyright defense-the legal analogue of its "freedom to innovate" claim-as an argument that "borders upon the frivolous." Microsoft, 253 F.3d at 63 .
} 
fited because the case was not resolved until after the Bush administration took office. A Gore administration would likely have been tough on Microsoft in order to restore competition. The Bush administration instead gave Microsoft a generous settlement, with only limited restrictions on the company's conduct. ${ }^{104}$

On the outside-the-courthouse question of the legitimacy of antitrust enforcement, by contrast, the pro-antitrust outcome was clear and powerful. In its wake, Microsoft's public relations attack on the legitimacy of antitrust has never gained traction.

One way it might have, but did not, is through the Supreme Court's 2004 decision in Trinko. ${ }^{105}$ In that case, a class of local telephone service customers alleged that Verizon, an incumbent local exchange carrier, had protected its monopoly prices from erosion by denying interconnection services to entrants seeking to offer competing local telephone service. Verizon was obligated to provide new entrants with interconnection services under the Telecommunications Act of 1996. Justice Scalia's opinion for the Court held that Verizon's unilateral refusal to assist its rivals did not state a claim under the Sherman Act.

Trinko can be read narrowly, ${ }^{106}$ as precluding monopolization liability in a setting in which a separate statutory scheme provided for extensive regulation aimed at promoting competition. ${ }^{107}$ But the sweeping rhetoric of Justice Scalia's opinion for the Court allows for a broader reading that adopts some of the arguments in the economic policy critique of the law governing monopolization through non-price exclusionary conduct and hints at the political critique. ${ }^{108} \mathrm{Had}$ Microsoft come out differ-

\footnotetext{
104 The settlement's terms were what one might expect from an enforcer skeptical about the case, and perhaps sympathetic to Microsoft's broad out-of-the-courthouse attack on antitrust, who made a good-faith effort to resolve the case consistent with the law. See Charles A. James, The Real Microsoft Case and Settlement, ANTirrust, Fall 2001, at 58. Not surprisingly, though ironically, given that the government had prevailed in court, the settlement was championed by those most critical of the government's case and criticized by the case's strongest supporters.

105540 U.S. 398.

106 See Nobody v. Clear Channel Commc'ns, Inc., 311 F. Supp. 2d 1048, 1112-14 (D. Colo. 2004) (limiting Trinko to regulated industry settings); but see John Doe $1 \mathrm{v}$. Abbott Labs., 571 F.3d 930 (9th Cir. 2009) (applying Trinko and linkLine outside the regulated industries context).

107 The statute incorporated specific mechanisms for promoting competition by requiring incumbent monopolists to deal with entrants.

108 Justice Scalia stated:

The mere possession of monopoly power, and the concomitant charging of monopoly prices, is not only not unlawful; it is an important element of the freemarket system. The opportunity to charge monopoly prices-at least for a short period-is what attracts "business acumen" in the first place; it induces risk taking that produces innovation and economic growth. ... Firms may acquire mo-
} 
ently, Trinko might have gone farther to question the legitimacy of the antitrust bar on monopolization.

Another way Microsoft's public relations attack on antitrust might have gained traction, but did not, is through the deliberations of the Antitrust Modernization Commission (AMC). Congressman James Sensenbrenner, then the Chairman of the House Judiciary Committee, introduced the legislation that led eventually to the creation of the AMC the day before the D.C. Circuit released its en banc decision on liability in the government's monopolization case against Microsoft. ${ }^{109}$ Sensenbrenner framed for AMC consideration several issues that arose in the Microsoft litigation, ${ }^{10}$ all likely familiar to the AMC Commissioners. ${ }^{11}$

nopoly power by establishing an infrastructure that renders them uniquely suited to serve their customers. Compelling such firms to share the source of their advantage is in some tension with the underlying purpose of antitrust law, since it may lessen the incentive for the monopolist, the rival, or both to invest in those economically beneficial facilities.

Trinko, 540 U.S. at 407-08.

${ }^{109}$ Act to establish the Antitust Modernization Commission, H.R. 2215 (2001) (introduced June 27, 2001) (enacted as Pub. L. No. 107-273 on Nov. 2, 2002). The text of the statute is available at http://govinfo.library.unt.edu/amc/pdf/statute/amc_act.pdf.

${ }^{110}$ When Congressman Sensenbrenner introduced his bill, he indicated that he wanted the AMC to investigate the role of intellectual property law in antitrust law, how antitrust enforcement should change in the global economy, and the role of state attorneys general in enforcing antitrust laws. Press Release, Rep. F. James Sensenbrenner, Chairman, Committee on the Judiciary, U.S. House of Representatives, Sensenbrenner Introduces Antitrust Study Commission Legislation (June 27, 2001), available at http://judiciary. house.gov/legacy/news_062701.hum. At the AMC's first public hearing in 2004, which took place in the hearing room of the House Judiciary Committee, Chairman Sensenbrenner amplified on these ideas. On the first, he wanted the antitrust laws "calibrated" to reflect an "increasingly information-driven digital economy." On the second, he was concerned about subjecting U.S. firms to conflicting enforcement regimes abroad. He specifically noted the EU's investigation of Microsoft, and called on foreign enforcers to exercise comity in order to avoid unfair and discriminatory treatment of U.S. firms. On the third, he raised the problem of inconsistent federal and state antitrust standards. These three problems were salient for Chairman Sensenbrenner at least in part because they came up in the Microsoft antitrust litigation. Any case of this magnitude almost necessarily would raise important questions about antitrust law and policy, so it is not surprising that those questions framed a broader public debate. In his 2004 charge to the AMC, Chairman Sensenbrenner added two more issues that were probably not suggested specifically by the Microsoft case. He was worried that international trade agencies like the WTO might supplant the antitrust agencies, particularly with respect to harmonizing the antitrust and intellectual property laws, and he was concerned about the circumvention of the antitrust laws through exemptions for regulated industries. Transcript of July 15, 2004 Meeting, Antitrust Modernization Commission (testimony of Hon. F. James Sensenbrenner), available at http://govinfo.library.unt.edu/amc/pdf/meetings/040715_Meeting_ Transcript_reform.pdf.

111 Many of the AMC's Commissioners had thought about some or all of Chairman Sensenbrenner's issues in connection with the Microsoft case itself. The Commission's Chair was a long-time partner of one of Microsoft's chief outside lawyers, and its members included Microsoft's lead trial attorney, a former Justice Department official who had been intimately involved in negotiating the government's settlement with Microsoft (who left 
One was suggestive of Microsoft's "freedom to innovate" argument: Sensenbrenner wanted the antitrust laws "calibrated" to reflect an "increasingly information-driven digital economy."112

When the AMC began its work, it asked for public comment on its agenda. It received responses from all over the political spectrum. Some commentators wanted more enforcement. Others echoed Microsoft's freedom to innovate critique. For example, conservative activist Grover Norquist, President of Americans for Tax Reform, wrote that "it seems clear that the antitrust laws, if they ever served a useful purpose, now only exist to stifle productivity growth and development of new products and services." 113

If the D.C. Circuit had split in the Microsoft case, with one opinion endorsing the freedom to innovate critique along the lines previously sketched and the Bush Justice Department seemingly endorsing that critique through its settlement with Microsoft, it is easy to imagine the AMC accepting invitations to recommend substantial changes to the antitrust laws in order to limit their scrutiny of high-tech firms like Microsoft. As matters actually transpired, though, the D.C. Circuit's unanimous decision on liability undermined Microsoft's legitimacy critique, and Microsoft itself no longer pressed that position once it settled with the government. Even if some AMC members would have liked to give the freedom to innovate critique a sympathetic hearing, therefore, the AMC had only limited political space to do so. ${ }^{114}$ Under such circumstances, it is not surprising that the AMC chose not to push for wholesale change. Its final report.endorsed the current approach to antitrust enforcement and suggested only limited reforms.

the AMC before its report issued), a former senior staffer for a leading Senate critic of Microsoft, and an economic consultant who had worked for Microsoft's rivals. The other Commissioners had comparable antitrust expertise. Cf. Jonathan Krim, A Less Public Path to Changes in Antitust, WASH. POST, May 12, 2005, at E1.

112 Transcript of July 15, 2004 Meeting, supra note 110, at 5.

113 Americans for Tax Reform, Comments Regarding Commission Issues for Study (filed before the Antitrust Modernization Commission, Sept. 9, 2004) (letter signed by Grover G. Norquist), http://govinfo.library.unt.edu/amc/comments/americanstaxreform.pdf.

${ }^{114}$ At the AMC hearings on exclusionary conduct, Charles (Rick) Rule, a former Assistant Attorney General for Antitrust, an outside counsel for Microsoft, and a leading critic of monopolization enforcement, declared that "in a perfect world," Section 2 could probably be repealed, but that as "a political realist" he recognized that that was not possible. Rule instead offered ten suggestions for modifying monopolization doctrine which, if accepted, would collectively mean "there wouldn't be a lot of behavior that would be caught by Section 2." Transcript of Sept. 19, 2005 Hearing on Exclusionary Conduct 13, Antitrust Modernization Commission, available at http://govinfo.library.unt.edu/amc/commission _hearings/pdf/050929_Exclus_Conduct_Transcript_reform.pdf. Professor Steven C. Salop, a leading defender of monopolization enforcement, responded that Rule sought to fix antitrust "in more or less the way I fixed our cat." Id. at 42. 
The political critique of monopolization enforcement has little traction today. By contrast, the economic and legal policy critiques remain the subject of a lively debate.

\section{PRESERVING A POLITICAL BARGAIN}

The three non-interventionist critiques of monopolization standards and enforcement, and the debates they have provoked, provide a window into the political economy of antitrust. This Part interprets those critiques as a challenge to a political bargain reached during the 1940s by which competition was adopted as national economic policy in preference to regulation or laissez-faire.

From this vantage point, the non-interventionist critics may have more than one motive. For some, the main objective is probably to reform the competition policy bargain in order to increase the efficiency gains to the economy, on the model of what occurred with respect to other areas of antitrust doctrine during antitrust's Chicago School revolution. For others, the point may be to use the monopolization debate as a wedge to overturn the competition policy bargain, as part of a broader attack on the post-New Deal regulatory state.

\section{A. Competition Policy as a Political Bargain}

A simple political economy interpretation of the non-interventionist challenge to monopolization standards and enforcement might view dominant firm defendants as concentrated political interests. ${ }^{115}$ As powerful political players, dominant firms may be peculiarly able to overcome the collective action problems that make it difficult to change antitrust law, and so achieve political influence over the regulatory scheme.

This simple theory is not persuasive, however. Antitrust enforcement is substantially insulated from capture because it implements a regulatory scheme of broad applicability, not an industry-specific one. ${ }^{116}$ More-

\footnotetext{
115 One public choice perspective views the Sherman Act as the product of majoritarian politics, legislated in a setting in which the benefits and costs of governmental action are. both widely distributed. James Q. Wilson, The Politics of Regulation 367 (1980). This interpretation has been questioned by other public choice scholars who emphasize the role of agricultural interests in the law's enactment. Donald J. Boudreaux et al., Antitrust Before the Sherman Act, in The Causes and Consequences of Antrtrust: The Public Chotce Perspective 255 (Fred S. McChesney \& William F. Shugart II eds., 1995).

116 The possibility of capture is also reduced by the requirement that the Justice Department prove its case in court. The Federal Trade Commission can try its cases administratively, subject to appellate review, but must similarly go to court to secure a preliminary injunction against a challenged merger. Although Congress has created a number of antitrust exemptions to favor specific industries, the antitrust rules established by the courts
} 
over, it is unlikely that dominant firms, which may be subject to monopolization enforcement, have more political power than industries as a whole, which may be subject to cartel enforcement-at least if the industry can plausibly solve its collective action problems, as may be the case for an industry with an oligopoly structure or an active trade association. In addition, the suggestion that dominant firms have particular political influence on antitrust enforcers or courts is at odds with the concern by non-interventionists that the enforcement agencies and courts are overly responsive to the complaints of unsuccessful and inefficient rivals to dominant firms.

The non-interventionist critiques are better interpreted against the background of a more complex political economy analysis of antitrust enforcement centered around the idea that large and diffuse interest groups in the United States reached an informal political bargain embracing antitrust by the middle of the 20th century. ${ }^{117}$ The "bargain" terminology may mislead to the extent it appears to suggest an explicit deal between organized political factions. Instead, the bargain should be understood as an informal political understanding that bridges an historically important political cleavage over the role of the government in regulating large firms. Framing this political outcome as a bargain highlights the problems of reaching and policing such an understanding.

Who are the parties to the bargain? The national policy of competition can be interpreted as a coordinated arrangement between two large and diffuse interest groups, here "consumers" (a group that historically also included farmers and small business) and producers (large firms). ${ }^{118}$

are generally applied in a similar way across industries. According to two former senior FTC officials, however, the oil industry is an exception. Timothy J. Muris \& Richard G. Parker, A Dozen Facts You Should Know About Antitrust and the Oil Industry 5 (June 2007), available at http://www.uschamber.com/NR/rdonlyres/ecw4z24weaarlxr4y4owljh spsc4melp4frhuazd5ppvlkte5zvy6ngoyaegioeds3fjoaxatl53gqz7s3v57gl3tte/070625oilreport.pdf ("The petroleum industry receives closer scrutiny from antitrust authorities than any other industry.").

${ }^{117}$ See generally Baker, Political Bargain, supra note 40. Cf. Kovacic, Enforcement Norms, supra note 6 (highlighting continuities in antitrust policy independent of the political party in power).

118 Baker, Political Bargain, supra note 40, at 519-22. The underlying model assumes that a diffuse interest group, such as consumers or producers, can more easily solve its collective action problems under conditions of adversity than success, and that a diffuse interest group that succeeds politically would be unable to lock in its success permanently by making it difficult for its unsuccessful rival interest group to mobilize in the future. Under such circumstances, the one-shot political interaction between producers and consumers would lead to regulatory cycles: if one group gets the upper hand, and can introduce policies that appropriate rents from the other group, that outcome motivates the losing group to mobilize its political resources more effectively and overturn the undesirable regulatory regime. An efficiency-enhancing competition policy bargain is possible in this 
These groups have potentially adverse interests. If either is able to control the political process, it would pick a regulatory policy that shifts rents away from the other group: consumers would regulate large firms and redistribute their rents, while producers would adopt a laissez-faire policy that permits firms to exercise market power. ${ }^{119} \mathrm{~A}$ political equilibrium that maximizes the joint surplus of the actors-here achieving the efficiency gains from selecting competition enforcement as national policy in preference to regulation or laissez-faire-is not inevitable. ${ }^{120}$ But it can arise if the interest groups recognize that their political interaction is ongoing, ${ }^{121}$ as plausibly occurred with the competition policy bargain reached during the mid-20th century.

How was the bargain reached? In brief summary, for many decades before the 1940s, big business had fought for a non-interventionist policy of self-regulation while consumer, farmer, and small business interests advocated regulatory alternatives. This dispute was a central domestic policy issue in the 1912 presidential election and during the Great Depression, for example. The tussle between these coalitions meant that regulatory policy shifted unstably between pro-consumer and pro-business positions.

During the 1940s, these interest groups collectively accepted an intermediate, antitrust-focused approach to business regulation that gave close scrutiny to firm conduct in concentrated markets without engag-

setup if consumers and producers come to recognize that they interact politically in repeated play.

119 The division of the polity into two broad groups, consumers and producers, ignores the difficulty of classifying individuals who see themselves as consumers at home but identify with producer interests at work, and the difficulty classifying firms that are sellers in their output markets but buyers in their input markets. It also downplays important distinctions within each group (such as the different interests among consumers, farmers, and small business within the "consumer" interest group), and puts aside the division between those in the consumer interest group who sought to restore competition by breaking up large firms and those who sought to domesticate large firms through governmental supervision and planning. Notwithstanding these qualifications, the Populist and Progressive accounts of domestic politics as a struggle between the people and the interests captures an important aspect of historical debates over economy-wide regulatory policy. See generally id. at 495-98.

${ }^{120}$ In the model, neither interest group would select antitrust over its preferred outcome in a one-shot interaction, notwithstanding the possibility of also appropriating the resulting efficiency gains because it would be difficult for each interest group to mobilize politically in favor of that more complex outcome to the extent that doing so would require downplaying the sense of grievance. (Analogously, cartels typically exercise market power by reducing output below the competitive level, notwithstanding the theoretical possibility that they could sell more and appropriate some of the efficiency gains, for example, through complex pricing, such as a two-part tariff.)

121 Id. The application of the Folk Theorem presumes either an infinitely repeated political interaction or, perhaps more plausibly, a finitely repeated interaction with uncertain termination. 
ing in ongoing regulatory supervision or systematically sacrificing the efficiencies of the large firm form of business enterprise. ${ }^{122}$ Each interest group gave up its preferred policy in reaching a political accommodation that allowed them to share the efficiency gains from competition. ${ }^{123}$ A political debate that had for decades seemed incapable of resolution began to fade in salience. By 1964 historian Richard Hofstatder could describe the antitrust movement as "one of the faded passions of American reform." 124

What are the terms of the political bargain? The political bargain can be described in broad strokes. It rejected national economic planning and direct economic regulation of large firms on the one hand, and a handsoff governmental role on the other hand, in favor of a general policy of fostering and protecting competition. ${ }^{125}$ Because the bargain was reached informally, "competition" was not defined with contractual pre-

122 The unhappy experience with the National Recovery Administration during the 1930 s had placed advocates of industrial self-regulation and those favoring broad governmental planning on the political defensive. When the impetus to regulate big business became more urgent with the recession of 1938, Thurman Arnold, appointed in 1938 to lead the Justice Department's Antitrust Division, reinvigorated antitrust enforcement with an approach that gave close scrutiny to firms in concentrated markets without engaging in ongoing regulatory supervision or forcing the firms to sacrifice scale and scope economies. This approach was accepted by the courts during the 1940 s and by Congress when it toughened the anti-merger statute in 1950, and the enforcement norms established then continue to shape competition policy today. See generally Baker, Political Bargain, supra note 40, at 501-02. Cf. Anne Mayhew, How American Economists Came to Love the Sherman Antitmest Act, in From Interwar Pluralism to Postwar Neoclassicism 179 (Mary S. Morgan \& Malcolm Rutherford eds., 1998) (professional economists were unenthusiastic about the Sherman Act in 1890 but embraced it by the end of the 1930s). Two alternative explanations for the decline in political salience of regulatory policy since the 1940spost-World War II prosperity and the Cold War political competition between the U.S. and U.S.S.R-are considered in Baker, supra, at 504 n.80.

${ }^{123}$ This outcome was not inevitable, as political institutions do not necessarily evolve to capture efficiency gains. See generally Baker, supra note 40, at 492-93.

124 Richard Hofstadter, What Happened to the Antitmust Movement? in The Paranoid Style in American Politics, and Other Essays 188 (1979 reprint). Similarly, antitrust had first appeared in political party platforms in 1888 and was routinely endorsed every four years thereafter for a century. But it largely disappeared from those platforms after 1988. Baker, Political Bargain, supra note 40, at 503.

125 The adoption of a competition policy bargain did not lead to the immediate deregulation of those sectors of the economy that had been subject to ongoing regulatory supervision-transportation, financial services, electric power, and communications. But the deregulation movement that began during the 1980 s followed its logic by narrowing regulation in these sectors to more closely mirror the scope of likely natural monopolies (where competition is not feasible). The competition policy bargain did not affect the legitimacy of economic regulation intended to address market failures, such as externalities (like pollution), provision of public goods, natural monopoly, problems with markets arising from asymmetric information (such as moral hazard and adverse selection), or the high transactions costs of coordination and standard-setting. Nor did it affect the legitimacy of social insurance. 
cision. Its contours were reflected in the antitrust approach accepted during the 1940s by all three branches of the federal government: the United States would supervise closely large firms in concentrated industries through case-by-case antitrust enforcement rather than relying on business self-regulation, active and ongoing regulatory supervision, or systematic industrial restructuring that might sacrifice scale and scope economies. ${ }^{126}$ Antitrust rules can thus be understood as institutions developed to define, protect, and enforce the political bargain (including the ability to reform the bargain, as occurred in response to Chicago School critiques of structural era rules).

Yet the political bargain does not determine closely the specifics of the doctrinal rules. The antitrust rules developed by the Supreme Court during the 1980s are on the whole consistent with it, but more interventionist rules would also be largely consistent with the bargain, ${ }^{127}$ and, in antitrust, the courts have generally been assigned the institutional role of specifying the details. This allows the bargain to change over time, most notably during the Chicago School revolution. In general, the new rules developed by the Supreme Court then removed impediments to efficiency-enhancing business conduct. But in protecting producers from overly stringent antitrust rules, the Court pushed the rules so that they now approach the non-interventionist edge of the permissible spectrum. ${ }^{128}$

How was the bargain modified? Political debate returned with a shift in antitrust policy during the late 1970s and 1980s. During that period, the Supreme Court revised many if not most aspects of antitrust law along the lines suggested by legal and economic commentators loosely associated with the University of Chicago. ${ }^{129}$ The antitrust laws changed dra-

\footnotetext{
126 See generally Baker, Political Bargain, supra note 40, at 501-02. "To an important extent ... the antitrust enforcement norms established then-particularly the objection to horizontal price fixing and to mergers leading to troublesome levels of market concentration-continue to shape competition policy today." Id. at 502.

${ }^{127} \mathrm{~A}$ set of more interventionist rules, likely also in large part consistent with the political bargain, has been proposed by the American Antitrust Institute. AMERICAN ANTITRUST Institute, The Next Antrtrust Agenda: The American Antitrust Institute's Transition Report on COMPETITION POLICY (2008), available at http://www.antitrustinstitute. $\mathrm{org} /$ archives/transitionreport.ashx.

${ }^{128} \mathrm{Cf}$. Baker, Political Bargain, supra note 40, at 519-22 (present-day enforcers and courts should be more concerned about the possibility that antitrust rules might become so noninterventionist as to permit the exercise of market power, and so undermine consumer confidence that competition is superior to regulation and redistribution, than about the reverse possibility that the antitrust laws are so stringent as to lead producers to favor scrapping the political bargain).

${ }^{129}$ See generally Baker, A Preface to Post-Chicago Antitrust, supra note 26. The breadth of doctrinal change is underscored by Judge Douglas Ginsburg's comment that the law governing tying was the "last man standing." Douglas H. Ginsburg, Judge, U.S. Court of Ap-
} 
matically but not fundamentally. To a substantial extent, the shift in antitrust doctrine during the 1980s reflected a bipartisan consensus in favor of reforming antitrust rules to enhance the efficiency gains arising from competition policy. ${ }^{130}$ Under this interpretation, antitrust's Chicago School revolution reaffirms, rather than undermines, the view that the United States had by 1950 adopted competition policy as a political bargain. ${ }^{131}$

How is the bargain enforced? The competition policy bargain is enforced in two senses. Its terms are enforced narrowly through the application of antitrust rules to resolve disputes - that is, in the day-to-day prosecutorial efforts of government agencies and private plaintiffs and in the decisions of the courts. The bargain is enforced more broadly when antitrust rules change, as political actors evaluate and respond to those developments to ensure that the modified set of rules remains within a range consistent with relying on competition rather than substituting business self-regulation or close regulatory supervision. If those political constraints fail, modifications to antitrust standards may undermine the bargain. Otherwise, modifications may implement it or improve it.

\section{B. Why Might a Political Bargain Change?}

From an economic point of view, the political bargain over competition policy-an informal political détente between producers and con-

peals for the D.C. Circuit, Remarks at the Luncheon Roundtable Discussion with Federal Court of Appeal Judges, ABA Section of Antitrust Law Spring Meeting (Mar. 25, 2009).

130 These years saw controversy within the antitrust field over how to revise the rules, but also general recognition that structural-era antitrust rules frequently sacrificed beneficial production efficiencies and would benefit from reform. See LAWRENCE A. SULLIVAN \& WARren S. Grimes, The Law of Antitrust: An Integrated Handbook $\$ 1.3$ at 7 (2d ed. 2006) ("By the mid-1970s, a sense that some court decisions had suppressed conduct that was efficient and the contemporaneous growth in influence of the Chicago School of Economics began tempering enforcement policy."). Cf. Thomas E. Kauper, Influence of Conservative Economic Analysis on the Development of the Law of Antitrust, in How THE CHIcago School Overshot the Mark: The Effect of Conservative Economic Analysis on U.S. Antitrust 40, 42-44 (Robert Pitofsky ed., 2008) (while Chicago criticisms of the antitrust doctrines of the $1950 \mathrm{~s}$ and $1960 \mathrm{~s}$ were influential in bringing about change, those doctrines were often easy targets for ridicule and were also criticized by a number of influential non-Chicagoans, such as Phillip Areeda, Donald Turner, and Robert Pitofsky).

${ }^{131}$ Baker, Political Bargain, supra note 40, at 505-15. That is, antitrust's Chicago School revolution is better understood as reform of the antitrust laws to increase the efficiency gains from competition and to avoid the possibility that the political bargain would become disadvantageous for producers, or else as a thwarted attempt by producers to renege on that political bargain, rather than as a successful attempt by producers to induce the political system to discard competition policy in favor of a pro-producer regulatory regime permitting the exercise of market power. 
sumers-raises enforcement problems similar to those facing a cartel. ${ }^{132}$ That is, the parties to the bargain may see an opportunity to profit by cheating-here manipulating the political system to transform antitrust rules so they no longer foster efficient firm behavior but instead permit the exercise of market power (producer cheating) or implement redistributive regulation (consumer cheating). To preserve the competition policy bargain, the political system must prevent those changes in the rules that would undermine the bargain in this way, much as a cartel must prevent cheating by its members.

The cartel analogy suggests three reasons why the outcome of the competition policy bargain-particularly the standards developed to implement the bargain in applying the antitrust laws-might change under pressure from non-interventionists, the primary source of recent criticism of monopolization standards. First, rule changes made under non-interventionist pressure might reflect producer cheating, by which large firms foster changes in the rules consistent with the bargain breaking down. Second, the terms of the bargain might, from the start, incorporate variations in doctrinal rules or enforcement standards that favor producers when necessary to prevent cheating by large firms (thereby ensuring that cheating never occurs). Finally, pro-producer changes in the rules might reflect renegotiation of the terms of the bargain to enhance the gains to both parties by removing impediments to procompetitive producer behavior. These possible interpretations of the early 21 st century controversy over monopolization standards and enforcement policy are evaluated in turn.

\section{Political Mobilization to Overturn the Competition Policy Bargain}

First, the terms of the bargain may change because the agreement has broken down or is breaking down. ${ }^{133}$ One of the interest groups that is a

\footnotetext{
132 See id. The similarity between the enforcement problems facing the political bargain and cartels makes the long duration of the political bargain (now into its second halfcentury) appear unsurprising: though some cartel agreements are very short lived, others last for decades. Margaret C. Levenstein \& Valerie Y. Suslow, What Determines Cartel Success? 44 J. Econ. LrT. 43, 49-57 (2006). The DeBeers diamond cartel has lasted more than a century.

${ }^{139}$ It is no surprise that the political bargain adopting competition policy has remained in force for decades, notwithstanding difficulties in achieving cooperative outcomes of multi-party prisoner's dilemmas and enforcing those outcomes to prevent cheating . $C f$. Avinash Dixit, Governance Institutions and Economic Activity, 99 Am. ECON. Rev. 5 (2009) (highlighting such problems). These difficulties tend to be avoided in enforcing the competition policy bargain for several reasons. First, the dynamic equilibrium that can be achieved through repeated play of a prisoner's dilemma is selfenforcing, so long as the external environment does not change. Second, the producer and consumer groups that reached the bargain would be expected to have difficulty mobilizing politically to cheat, because of the problems inherent in solving the collective action problems facing a large
} 
party to the political bargain-here, large firms that might prefer that the nation switch to a laissez-faire framework-may cheat by mobilizing political support for a change in the rules, leading the bargain to collapse. ${ }^{134}$

If cheating by large firms were to occur, one would expect to observe a broad political mobilization of actors associated with producer interests in support of efforts to reject existing competition policy rules like the monopolization standards that are now the focus of controversy. Such a mobilization would likely influence multiple government institutions, particularly those on the front lines in implementing the political bargain. ${ }^{135}$ At the federal level, one might expect to see reduced enforcement by the Antitrust Division or the FTC, Justice Department advocacy of non-interventionist views before the courts through amicus briefs, Congress employing oversight of the enforcement agencies and courts to question the scope of traditional rules, congressional action to cut enforcement agency budgets or limit or repeal the current antitrust rules, or the Supreme Court reaching out to take monopolization cases in order to limit or overturn monopolization rules. ${ }^{136}$

and diffuse group. And if one interest group threatened to overturn the bargain, that would encourage counter-mobilization by the opposing interest group. See generally Baker, Political Bargain, supra note 40, at 487-90. Third, the institutions involved in implementing the political bargain are often slow to change and may have a stake in the bargain's success.

134 The possibility that the bargain might be renegotiated after its collapse can be thought of as change through renegotiation, which is discussed below.

135 A sustained political mobilization would likely be required, moreover, in order to achieve change. Although antitrust's Chicago School revolution ultimately served to reform the competition policy bargain, rather than overthrow it, Congress and the states exhibited suspicion as to whether the proposed reforms were undermining the bargain and slowed the Chicago tide in some areas. Id. at 501-10. In 1984, for example, Congress limited the Assistant Attorney General's ability to argue in court for discarding the per se rule against resale price maintenance, thereby signaling its displeasure to both the Executive Branch and the Supreme Court. The result was that the Court, abetted by the Executive, narrowed the per se rule in various ways without discarding it. The rule was not overturned until 2008. See generally GAVI. ET AL., supra note 18, at 370-75.

136 Cf. Baker, Political Bargain, supra note 40, at 506-08 (similar features characterized the transition from antitrust's structural era to its Chicago School era). If the political bargain has broken down because producer interests have chosen to renege, it may also be possible to understand why the producers found cheating worthwhile. One possibility is a change in the payoffs that lowers the producer share of the efficiency gains from competition policy or raises the producer gains from the exercise of market power. Another is an increase in the discount rate that leads producers to act in a present-oriented way (and thus to ignore the possibility that their success in overturning the competition bargain would engender a countervailing mobilization by consumers to regulate the large firms). A third possibility is that the producer coalition has been captured by a subgroup that favors reneging (perhaps monopolists under investigation), in a setting where collective action problems limit the ability of those large firms that favor continuation of the competition policy bargain from stopping the minority. 
A case can be made for this interpretation of the recent controversy over monopolization standards by placing that dispute in a broader context. If the legal, economic, and political critiques of monopolization law reflect a political mobilization by business interests to overturn the competition policy bargain in favor of laissez-faire, antitrust is probably not the primary arena for that political contest. Antitrust is more likely a secondary battleground in a larger effort by some conservative political interests, perhaps including the large businesses that might care about monopolization, ${ }^{137}$ to undo the regulatory and social insurance programs created during the New Deal.

This broader political controversy can be briefly sketched. ${ }^{138}$ Although some economic conservatives have never accepted the legitimacy of New Deal policy innovations, those programs had become entrenched by the 1950 s, even in the Republican Party, the most common political home for critics of government involvement in the economy. ${ }^{139}$ Then the economy went sour. Between 1973 and 1984, the United States experienced inflation, an energy shortage, three recessions, new competition from foreign manufacturers in lower wage nations, slowed productivity growth, and sluggish income growth for workers. This decade of economic stagnation arrived in the wake of the Civil Rights movement and new rules to protect the environment and worker safety. These worthy governmental initiatives had unintended political consequences: they generated public concern about the extent and costs of government regulation. Business interests stoked that concern by funding think tanks and other vehicles for promoting opposition to the role of the govern-

\footnotetext{
${ }^{137}$ The high-profile role of Microsoft in making the contemporary political argument against antitrust, discussed above, illustrates the potential for some big business interests to conclude that, on the whole, they would benefit if antitrust law were to lose its teeth. With its antitrust issues largely resolved in the United States, however, Microsoft has more recently encouraged the Justice Department to undertake close scrutiny of Google's business conduct in markets in which Google and Microsoft compete. Google has to date not chosen to attack the legitimacy of monopolization enforcement, preferring to argue that it lacks market power (that competition is one click away).

198 For a description of the broader context in this paragraph, see KIM PHILlips-Fein, Invisible Hands: The Making of the Conservative Movement from the New Deal to Reagan (2009); Monica Prasad, The Politics of Free Markets: The Rise of Neoliberal Economic Policies in Britain, France, Germany \& the United States (2006); Mark A. Smith, The Right Talk: How Conservatives Transformed the Great Society into the Economic Sogiety (2007); Steven M. Teles, The Rise of the Conservative Legal Movement: The Battle for Control of the LAw (2008).

139 "Should any political party attempt to abolish social security, unemployment insurance, and eliminate labor laws and farm programs," President Eisenhower, a Republican, observed, "you would not hear of that party again in our political history." PhILLIPS-FeIN, supra note 138, at 56 .
} 
ment in economic affairs. ${ }^{140}$ These developments favored the conservative agenda of "getting government off the backs of the American people" and set the stage for a thirty-year conservative counter-revolution. A property tax revolt began in California in 1978, and Ronald Reagan rode the anti-tax and anti-government tide to the White House in 1980 .

Since then, and lasting at least through mid-2008, the domestic economic policy agenda in the United States has been set largely by noninterventionist conservatives. The Ronald Reagan and George W. Bush administrations in particular, and the elevation of Newt Gingrich to Speaker of the House during the Clinton administration, gave the opposition to "big government" both legitimacy and a platform. While the Clinton administration may have tempered the rough edges, even during the 1990s the domestic political debate on economic issues emphasized conservative concerns-control of federal budget deficits and reducing the scope of the welfare system-and the Clinton administration's high-profile political push to provide health care for the uninsured was opposed by conservatives and did not succeed. ${ }^{141}$

The economic ideal for non-interventionist conservatives is a government that simply protects contract and property rights and otherwise stays out of the way of private economic activity. ${ }^{142}$ To achieve that end politically, they have targeted taxes and regulation-an essential nutrient and a widely employed tool of government, respectively. Some conservatives justify this approach instrumentally, as the best way to keep the "dead hand" of government from impeding the "invisible economic hand" of growth and prosperity. Others see the free market as a critical means of promoting freedom and morality. Whatever the justification for reducing the role of government in economic affairs, the election of Ronald Reagan marked a sea change in American politics, after which New Deal institutions were placed on the defensive.

The recent monopolization controversy could be interpreted as an instance of this broad anti-big government effort spilling over to antitrust. Some political actors with longstanding and deep ties to the non-

\footnotetext{
140 These organizations generally operated by identifying like-minded scholars for financial support and helping them raise their public profile, not by paying scholars to change their views.

141 In his 1996 State of the Union message, President Clinton made headlines by adopting non-interventionist rhetoric, declaring that the "era of big government is over." Alison Mitchell, State of the Union: The Overview; Clinton Offers Challenge to Nation, Declaring "Era of Big Government is Over, "N.Y. Times, Jan. 24, 1996, at Al.

142 Many conservatives favor a more ambitious role for government in non-economic realms, however, particularly to promote national defense and to protect moral values.
} 
interventionist wing of the Republican Party, longstanding hostility to New Deal programs, and a deep commitment to the conservative political program of cutting taxes, shrinking government, and repealing regulation have argued against antitrust enforcement ${ }^{143}$ - suggesting a tie between hostility to the antitrust enterprise and their broader political program.

Non-interventionist conservative views about antitrust made substantial headway during the George W. Bush administration. As previously recounted, Congress appeared sympathetic to a less-interventionist antitrust in 2002, when it created the Antitrust Modernization Commission and charged it with proposing updates to the antitrust laws against the background of Microsoft's political argument that questioned monopolization standards. ${ }^{144}$ The Supreme Court's dicta in Trinko, a 2004 decision, arguably endorsed the non-interventionist perspective on monopolization in a majority opinion that obtained the vote of six justices. ${ }^{145}$ The Justice Department brought no monopolization cases between 2001 and 2008, except for three technical violations. ${ }^{146}$ The Antitrust Division seemed to support the non-interventionist view of monopolization in its 2004 amicus brief in Trinko and, in 2008, in its Sec-

${ }^{143}$ E.g., Americans for Tax Reform, supra note 113. See An Open Letter to President Clinton from 240 Economists on Antitrust Protectionism (June 2, 1999), available at http://www.independent.org/issues/article.asp?id=483.

144 Congress and the courts have also created at least thirty antitrust exemptions. See AMC Report, supra note 55, at 378; ABA Section of Antitrust Law, Feneral Statutory EXEMPTIONS FRom ANTITRUST LAW (Monograph No. 24) (2007). Also, in 1995, the House Judiciary Committee ended its longstanding antitrust subcommittee, seemingly signaling lack of interest in antitrust issues, although in succeeding years it occasionally created part-time antitrust task forces.

145 The Court's skepticism in Trinko about the value of antitrust enforcement, and its resulting preference for having competition issues decided exclusively by an industry regulator rather than preserving concurrent jurisdiction in an antitrust court, continued in 2007, when the Court expanded the implied antitrust immunity conferred by regulation under the securities laws. Credit Suisse Sec. (USA) LLC v. Billing, 551 U.S. 264 (2007). The Court has also recently expressed concern that antitrust cases in particular are subject to abuse by plaintiffs, who may exploit the threat of costly discovery, the uncertain outcome of jury trials, and the possibility of treble damages to extract unwarranted and excessively generous settlements from defendants. Bell Atl. Corp. v. Twombly, 550 U.S. 544, 556-57 (2007); id. at 589-90 (Stevens, J., dissenting); cf. Daniel A. Crane, linkLine's Institutional Suspicions, 2008-2009 CATO SuP. CT. Rev. 111, 127 (2009) (recent Supreme Court antitrust decisions evidence a "disdain for treble damages cases, juries, complaining competitors, and the antitrust plaintiffs' bar").

${ }^{146}$ Three horizontal merger complain ts brought late during the George W. Bush administration alleged mergers to monopoly, so were pleaded with a monopolization cause of action as well as under Section 7 of the Clayton Act. None involved exclusionary conduct. Complaint, United States v. Microsemi Corp., Civil Action No. 1:08cv1311 (ATJ/JFA) (E.D. Va. Dec. 18, 2008); Complaint, United States v. Amsted Indus., Inc., Civ. No. 1: 07CV-00710 (D.D.C. Apr. 18. 2007); Complaint, United States v. Daily Gazette Co., 567 F. Supp. 2d 859 (S.D. W.Va. 2008). 
tion 2 report. ${ }^{147}$ At times during those years it appeared possible that all three branches of the federal government were shifting to adopt the non-interventionist perspective toward monopolization-for the first time since the political bargain was established in the mid-20th century. ${ }^{148}$ Adoption of the non-interventionist perspective by all three branches could lead to a broad reworking of the political bargain or repeal of the bargain altogether.

These gestures toward a new, non-interventionist antitrust policy have not added up to political mobilization to overturn the competition policy bargain, however, because they have been uncoordinated in timing, they have not drawn bipartisan support, ${ }^{149}$ and to date they have fallen short of major change: ${ }^{150}$ The Antitrust Modernization Commission chose to reaffirm longstanding antitrust norms rather than seeking to chart a new course, the Federal Trade Commission has continued to bring monopolization cases, ${ }^{151}$ and a majority of FTC Commissioners pointedly dissented from the Justice Department's views regarding monopolization in the Section 2 report. During the past three decades, moreover, the heads of the Antitrust Division who have been most critical of antitrust rules governing exclusionary conduct generally, and mo-

\footnotetext{
147 Professor Herbert Hovenkamp, a mainstream antitrust scholar and co-author of the leading antitrust treatise, has described the DOJ Report as "extremely tolerant of singlefirm conduct." Herbert Hovenkamp, The Obama Administration and $\S 2$ of the Sherman Act 1 (July 2009), http://ssrn.com/abstract=1437688. But cf. Brief of the United States as Amicus Curiae, 3M Co. v. LePage's Inc., 542 U.S. 953 (2004), available at http://www. justice.gov/atr/cases/f203900/203900.pdf (DOJ recommended that the Supreme Court not review a verdict for the plaintiff in a monopolization case involving bundled rebates, in order to allow further development of the law in the lower courts).

${ }^{148}$ During antitrust's Chicago School revolution, two branches of the federal government-the courts and the Executive branch-were enthusiastic about the new approach. But Congress (as well as the states) questioned various aspects, helping ensure that the outcome was limited to reforming the political bargain rather than reneging on it. Baker Political Bargain, supra note 40, at 505-15.

149 Cf. How the Chicago School Overshot the Mark, supra note 130 (critical response to recent trends in antitrust law and enforcement policy from commentators who argue that those trends do not enhance efficiency and consumer welfare). (I co-authored one of the chapters in this volume, on merger policy.) See also supra Part I.B (discussing the economic counterarguments that have been offered in response to the non-interventionist policy critique of monopolization standards). By contrast, the Chicago School concerns about the overbreadth of structural era antitrust doctrines were more generally shared by Democrats and Republicans, although the precise nature of the appropriate reforms was contested and the traditional rules had some strong defenders.

150 Since the late $1970 \mathrm{~s}$, the Supreme Court has reformed antitrust doctrines to make them consistent with the Chicago School perspective, and a supermajority in the Court today endorses that program. But the Court has not in general gone farther to question the legitimacy of the antitrust statutes, with the notable exception of the dicta on monopolization in the majority opinion in Trinko.

${ }^{151}$ William E. Kovacic, Rating the Competition Agencies: What Constitutes Good Performance? 16 Geo. Mason L. Rev. 903, 911 (2009).
} 
nopolization in particular, have simultaneously offered strong support to the rules against horizontal price fixing. ${ }^{152}$ The long-term conservative attack on big government is not closely tied to antitrust, and it is hard to see the non-interventionist pressure on monopolization rules as a key plank in the platform of the conservative political movement. ${ }^{153}$

The prospects for undoing the competition bargain under non-interventionist pressure appear to be waning. At the start of the 21st century, the popular mood might have accepted non-interventionist antitrust initiatives as beneficial pro-market steps. But that mood changed sharply during the late 2008 financial crisis and the recession that followed, shifting away from the non-interventionist approach to domestic economic policy generally and toward reaffirming the legitimacy of the regulatory and social insurance programs created during the New Deal. The shift was crystallized in late October 2008 when former Federal Reserve Chairman Alan Greenspan, a well-known advocate of the non-interventionist approach, admitted that the financial crisis had revealed a "flaw" in his free-market ideology. ${ }^{154}$

The Democratic electoral sweep in 2008 confirmed that popular support for criticism of government regulation had faded..$^{155}$ This setback to the broad conservative program could help insulate the competition policy bargain-which is only on the periphery of the efforts to roll back the New Deal-from the antitrust non-interventionists.

But some business interests have not given up on antitrust reform, ${ }^{156}$ and, more broadly, non-interventionists have mobilized politically

152 E.g., 60 Minutes with Charles F. Rule, Acting Assistant Attomey General, Antitrust Division, 56 Antitrust L.J. 261, 264 (1987); 60 Minutes with Charles F. Rule, Acting Assistant Attomey General, Antitrust Division, 57 AnTitrust L.J. 257 (1988); Barnett, supra note 72, at text after note 12 ("Our enforcement efforts against cartels have never been stronger.").

${ }^{153}$ Competition policy has never been at the forefront of the conservative economic agenda and the mid-20th century competition policy bargain survived antitrust's Chicago School revolution. Most Chicagoans supported reworking the antitrust rules, particularly to discard those aspects of prior doctrine tied more to social and political goals than to economic ones, rather than scrapping the antitrust laws entirely. Baker, Political Bargain, supra note 40 , at 510-11.

${ }^{154}$ Edmund L. Andrews, Greenspan Concedes Error on Regulation, N.Y. TImEs, Oct. 24, 2008, at B1. But of. Gerald F. Seib, U.S. Shifted Party, Not Ideology, WALl ST. J., Jan. 19, 2010, at A2 (polling data shows that throughout the January 2006 to January 2010 period, the U.S. has remained, ideologically, "a center to center-right nation").

155 Not surprisingly, in May 2009, the Obama administration's new Assistant Attorney General for Antitrust, Christine Varney, withdrew the previous administration's controversial Section 2 report and committed the Justice Department to "aggressively pursuing enforcement of Section 2 of the Sherman Act." Varney, supra note 13.

${ }^{156}$ As the new Obama administration was pondering what to do about the Section 2 report, the U.S. Chamber of Commerce argued that the report should be taken seriously and not be summarily dismissed. U.S. Chamber of Commerce, Bathwater Out. Now What to 
around their opposition to various aspects of health insurance reform..$^{157}$ A cautious analyst would wait to see whether the lessening of conservative control over the domestic policy agenda is confirmed in the way the Democrats implement their legislative agenda during the Obama administration, ${ }^{158}$ and in the results of national elections after the end of the 2008-2009 financial crisis and recession,, ${ }^{159}$ before concluding that the national economic agenda has shifted away from the concerns of the non-interventionists and that the competition policy bargain is safe from collateral damage in their larger fight to undermine the legitimacy of the government's modern role in the economy.

Do With Economic Analysis? Antitrust Standards for Unilateral Conduct: Sense and Consensus, Global Competition Pol'y, Mar. 10, 2009. During the first decade of the 21st century, moreover, some prominent members of the antitrust defense bar have pressed across-theboard criticisms of the antitrust system. E.g., Edwin S. Rockefeller, The Antitrust Religion (2007); Ky Ewing, Jr., Competition Rules for the 21st Century: Principles FROM AMERICA'S EXPERIENCE (2003). Both Rockefeller and Ewing have served as Chair of the ABA Section of Antitrust Law, the leading organization of competition lawyers in the United States.

${ }^{157}$ In the 2009 debate over the "public option" - the proposed creation of a government-run insurance plan to compete with private insurers-non-interventionist conservatives tended to view the proposal as a Trojan horse that would result in the eventual adoption of a government-run health care system to supplant private enterprise rather than, as many proponents claimed, the most promising method of creating a competitive insurance market to control insurance costs. Although a number of progressive supporters of the public option favored a government-run "single payer" health insurance system, they tended to view the public option as an acceptable but less preferable alternative. In this debate, the public option was defended primarily on competition grounds, as the best way to prevent the exercise of market power in the many regions in which private health insurance was controlled by a dominant firm. See generally Sheryl Gay Stolberg, Public Option Is Next Big Hurdle in Health Debate, N.Y. TIMEs, Oct. 15, 2009, at A1. The public option did not survive the legislative process, but at the end of 2009 one influential progressive commentator, Paul Krugman, nevertheless viewed what then appeared to be the likely enactment of a health care bill as "a historic moment" on the ground that it would represent "a rejection of the [conservative] view that the solution for all problems is to cut some taxes and remove some regulations." Paul Krugman, The Conscience of a Liberal, http://krugman.blogs.nytimes.com/ (Dec. 19, 2009, 3:55 pm EST). Not surprisingly, conservatives disagree: early in 2010, senior Republican party fundraisers sought to woo major donors with the slogan, "Save the country from trending toward Socialism!" Ben Smith, Exclusive: RNC Document Mocks Donors, Plays on "Fear," Politico, Mar. 3, 2010, http://www.politico.com/news/stories/0310/33866.html.

${ }_{158}$ At the start of the Obama administration, the legislative agenda of the Democrats in the White House and Congress emphasized universal health insurance, green energy, financial services regulation, and universal access to broadband communications. The non-interventionist concern about big government would tend to discourage major initiatives and broad reforms in these areas, even if those programs eschew redistribution and regulation in favor of fostering competition.

${ }^{159}$ On the run-up to the 2010 midterm elections, Republican prospects for success appear strong. If that outcome occurs, it may reflect popular unhappiness with the political process generally, rather than a preference for the non-interventionist approach to economic policy. See generally Charlie Cook, Ready, Aim, Fire, Repeat, CoOk Polttical ReP., Mar. 2, 2010, http://www.cookpolitical.com/node/5881. 


\section{A Bargain with Complex Rules}

Second, competition policy standards may change if the terms of the bargain incorporate variations in doctrinal rules or enforcement standards that respond to changes in the external environment in order to prevent cheating. ${ }^{160}$ In particular, antitrust rules or well-established enforcement policy could allow for more lenient treatment of producers for a time, triggered by changes in firm payoffs or discount rates that might seem to favor producer cheating, in order to make cheating less attractive to large firms than continuation of the bargain. ${ }^{161}$

Consistent with this possibility, some antitrust rules do exhibit flexibility. Court decisions and the Horizontal Merger Guidelines, for example, give failing firms and so-called "flailing" firms more ability to merge. ${ }^{162}$ But that flexibility is triggered by firm- and industry-specific developments rather than by changes in the calculus affecting broad interest groups. Other antitrust rules-particularly the rule of reason-could also in theory vary in application as necessary to ensure that interest groups share the efficiency benefits of competition, and not prefer cheating on the political bargain. But it is hard to argue that this is how such rules are applied in practice. ${ }^{163}$ Moreover, there is a great deal of continuity over time in antitrust norms, ${ }^{164}$ and if this were the explanation for the non-interventionist push to modify monopolization standards, those proposals would not be so controversial. Accordingly, this second possibility for explaining changes in antitrust rules within the framework of a competition policy bargain can be set aside as implausible.

\footnotetext{
${ }^{160}$ Similarly, Levenstein and Suslow conclude that successful cartels tend to develop organizational methods that confer side payments as necessary to deter firms from cheating following changes in the external environment, such as cyclical variation in demand, without renegotiation. Levenstein \& Suslow, supra note 132, at 67-74, 78; Margaret C. Levenstein \& Valerie Y. Suslow, Breaking Up is Hard to Do: Determinants of Cartel Duration 31 (Sept. 2009) (unpublished manuscript), available at http://papers.ssrn.com/sol3/papers. cfm?abstract_id=1471393.

${ }^{161}$ If the rules took this form, one would also expect the rules to shift rents toward consumers when necessary to prevent consumer cheating on the bargain.

162 See Int'1 Shoe Co. v. FTC, 280 U.S. 291 (1930) (failing firm defense); FTC v. Harbour Group Inv., 1990-2 Trade Cas. (CCH) I 69,247 (D.D.C. 1990) (same); United States v. Gen. Dynamics Corp., 415 U.S. 486, 506-08 (1974) (acquisition is unlikely to harm competition if acquired firm would not be a significant competitive force absent the merger) (sometimes termed a General Dynamics defense or "flailing" firm defense).

${ }^{163}$ Even after losing multiple hospital mergers, for example, the enforcement agencies have not concluded that the rules are different for hospitals. See Timothy J. Muris, Everything Old Is New Again: Health Care and Competition in the 21st Century (Nov. 7, 2002), available at http://www.ftc.gov/speeches/muris/murishealthcarespeech0211.pdf. Instead they have worked to improve their litigation tactics and continue to bring cases.

164 Kovacic, Enforcement Norms, supra note 6.
} 


\section{Attempts to Renegotiate the Rules}

Third, changing antitrust standards may reflect the renegotiation of individual rules to better advance their goals. ${ }^{165}$ In the case of antitrust rules, reform of the rules can increase the efficiency gains from competition in the economy. ${ }^{166}$ The recent controversy over monopolization rules, under this plausible interpretation, reflects the operation of a process by which proposals for reform of individual antitrust rules are refereed.

In this view, the key protagonists in the monopolization debate are litigants in individual court cases, the enforcement agencies in their enforcement decisions, briefs as party or amicus, and public statements, and interest groups seeking antitrust exemptions or other legislation from Congress. These parties propose approaches to applying (or modifying) legal doctrines, accompanied by a legal or economic policy argument defending those proposals as enhancing economic welfare. ${ }^{167}$ If the institutions that referee such proposals can successfully discriminate. between renegotiation proposals that benefit all the parties to the political bargain and those that undermine the bargain, the goals of the political bargain will be advanced, interest groups will see cheating on the bargain as less advantageous than sticking with it, and covert reneging by accretion of small decisions favoring one side of the bargain will be avoided.

During the late 1970s and through the 1980s-when antitrust's Chicago School revolution took root-the political bargain was reformed in a similar process, through the accumulation in the courts of individual changes in antitrust doctrine. Those doctrinal modifications likely increased the social surplus available from antitrust enforcement by targeting the rules more closely than before to prohibit inefficient conduct. ${ }^{168}$

\footnotetext{
165 Similarly, much apparent cheating in the cartel context is better understood as part of a process in which a cartel renegotiates the terms of its coordinated consensus. See Levenstein \& Suslow, supra note 132, at 78.

166 This is not an argument that all legal nules tend toward efficiency. Rather, the claim is that under the political bargain, antitrust rules in particular aim to promote efficiency in the economy and to ensure those gains are shared between producers and consumers. Accordingly, rule changes that enhance the joint surplus available for producers and consumers to split can advance the purpose of the bargain. See generally Baker, Political Bargain, supra note 40 , at 492 (distinguishing political bargain idea from the claim that the law tends toward efficient rules).

${ }_{167}$ Reforms that increase aggregate surplus and those that increase consumer surplus tend to go hand in hand, though sometimes such proposals can get caught up in a perennial antitust policy dispute as to the appropriate welfare standard. See id. at 515-22 (brief discussion with references to the literature).

168 Antitrust rules were refocused solely on economic goals, without consideration for the social and political goals that had informed those rules in the past. In consequence,
} 
Outside of predatory pricing, however, the Supreme Court left monopolization rules largely untouched. ${ }^{169}$ The contemporary non-interventionists in the monopolization controversy likely view their proposals as bids for reform consistent in spirit with the way many other antitrust doctrines were modified under Chicago School influence in the past. ${ }^{170}$

The interpretation of the monopolization controversy as a bid for renegotiation is consistent with the institutional role of the courts in specifying and implementing antitrust rules. The common law-like evolution of antitrust rules makes the federal courts an appropriate institution for refereeing proposals for reform of individual rules. Relying on courts to play this role tends to protect the political bargain in two ways. First, the process of legal reasoning and judicial decision making encourages judges to make principled decisions. In antitrust cases, judges hear arguments from both sides, the arguments frame economic policy questions, and judges look to establish principles that rationalize legal precedent and make economic sense. Modified legal rules generally do not have broad applicability until they are endorsed by multiple judges, including at least one panel of appellate judges.

Second, the role of precedent in judicial decision making, in theory, helps protect the political bargain. Lower courts are constrained by precedent; the Supreme Court is also constrained to a lesser extent. ${ }^{171}$ This constraint creates inertia, slowing the pace of change. Inertia also helps

the Chicago School reforms also had a distributional effect: they generally shifted the rules in a less interventionist direction, favoring producer interests.

${ }^{169}$ At the end of the $1970 \mathrm{~s}$, however, decisions by the Second Circuit and the FTC cut back on the expansive concept of exclusionary conduct employed in United States $v$. Aluminum Co. of America, 148 F.2d 416 (2d Cir. 1945) (Alcoa), the leading structural era monopolization decision. Berkey Photo, Inc. v. Eastman Kodak Co., 603 F.2d 263, 273 (2d Cir. 1979); E.I. du Pont de Nemours \& Co., 96 F.T.C. 653 (1980) (dismissing allegations that DuPont had attempted to monopolize the market for titanium dioxide through conduct similar to the conduct found to have supported monopolization in Alcoa).

170 Thus, contemporary critiques of monopolization rules generally favor less intervention.

171 The Supreme Court has at times overruled longstanding antitrust precedents. Doing so potentially conflicts with a norm of judicial conduct, leading the Court in such cases to provide an extensive legal and policy justification for its action. E.g., Leegin Creative Leather Prods., Inc. v. PSKS, Inc., 551 U.S. 877, 899-907 (2007); Continental T.V., Inc. v. GTE Sylvania Inc., 433 U.S. 36 (1977). When the Court wishes to change course, it may instead limit prior decisions, as it arguably has recently attempted to do with dicta characterizing Aspen Skiing. Verizon Commc'ns Inc. v. Law Office of Curtis V. Trinko, LLP, 540 U.S. 398, 399 (2004) ("Aspen Skiing is at or near the outer boundary of $\$ 2$ liability"); Pacific Bell Tel. Co. v. linkLine Commc'ns, Inc., 129 S. Ct. 1109,1118 (2009) (Aspen suggests that a firm's unilateral refusal to deal with its rivals can give rise to antitrust liability in "limited circumstances"). The latter approach keeps old precedents alive, so can delay legal change. When Assistant Attorney General Varney wished to signal her interest in monopolization enforcement, she thus was able to cite Aspen Skiing, Lorain Journal, and Microsof-all influential precedents predating Trinko that have not been over- 
protect the political bargain by facilitating the political mobilization of interest groups to counter legal change whenever the political bargain is placed in danger. ${ }^{172}$ But inertia may also work the other way if it makes it difficult for the courts, having begun to change doctrine, to swing back later.

Courts are not asked to play an explicitly political role in this process; they are merely asked to decide individual antitrust cases, relying on legal reasoning and precedent. This limited role does not threaten the legitimacy of the judicial branch. Accordingly, the process of litigationparticularly case selection by plaintiffs and the arguments proffered by litigants and amici-leads judges to respond to political forces indirectly, as they somehow must do if they are to protect a political bargain from erosion, without leading courts to undertake nakedly political decision making, as would undermine their legitimacy. ${ }^{173}$

It is an open question whether these advantages of the federal courts in reviewing proposals for renegotiation of the political bargain outweigh the disadvantage of relying on generalist judges, who lack antitrust expertise. ${ }^{174}$ Perhaps a specialized antitrust court would do better, although the experience of the Federal Circuit cautions that a specialized court may instead promote its field at the expense of the public interest. ${ }^{175}$

Other institutions could play the role of referee when renegotiation of the political bargain is proposed, and to some extent already do so. The enforcement agencies informally referee proposals when they set enforcement policy, and Congress could play this role by modifying statutes (though it rarely does in the antitrust area). As with the courts, these institutions also have features that create inertia, ${ }^{176}$ facilitating

ruled. Varney, supra note 13 . She ignored Trinko entirely, implicitly treating it as a narrow decision limited to regulated industries.

${ }^{172} \mathrm{Cf}$. McNollgast, The Political Economy of Law, in 2 HandBook of LaW AND Economics 1706 (A. Mitchell Polinsky \& Steven Shavell eds., 2007) (Congress often awaits complaints to trigger concern that an agency is not properly implementing congressional policy). In the political bargain model, adversity facilitates political mobilization by helping interest groups solve collective action problems. Baker, Political Bargain, supra note 40, at 487-90.

${ }^{173}$ Cf. Gerald N. Rosenberg, The Hollow Hope: Can Courts Bring About Social ChANGE? (2d ed. 2008) (the Supreme Court has a difficult time bringing about major social change through legal reform absent popular support for that outcome).

${ }^{174}$ However, appellate opinions by conservative antitrust experts, such as Frank Easterbrook, Douglas Ginsburg, and Richard Posner, may be more influential than most.

${ }^{175}$ See Rochelle Cooper Dreyfuss, In Search of Institutional Identity: The Federal Circuit Comes of Age, 23 Berkeley TeCh. L.J. 787 (2008); Craig Allen Nard \& John F. Duffy, Rethinking Patent Law's Uniformity Principle, 101 Nw. U. L. Rev. 1619 (2007).

${ }^{176}$ The continuity among career staff at the enforcement agencies helps preserve continuity in agency policies, and the presence of multiple enforcers-two federal agencies, 
counter-mobilization by threatened interest groups. Still, the present system, which assigns the primary refereeing role to the courts, was successful in preserving the political bargain while addressing the pressure for reform during antitrust's Chicago School revolution.

\section{PROSPECTS FOR DOCTRINAL CHANGE}

Against the background of viewing competition policy as a political bargain, the monopolization controversy instigated by conservative noninterventionists could play out in multiple ways. One possibility is that the non-interventionists will win. The Supreme Court could adopt a disproportionate impact or no economic sense test outside the price predation context, and justify that decision by accepting explicitly the economic policy arguments against monopolization enforcement while rejecting the counter-arguments-thereby signaling that exclusionary conduct cases against dominant firms will have become as difficult for plaintiffs (public and private) to win as predatory pricing cases are now. The same result could arise less dramatically through multiple decisions by the lower courts.

A non-interventionist victory of this sort could represent a rejection of the competition policy bargain in favor of greater reliance on business self-regulation. That would be a reasonable interpretation if monopolization standards do not change alone but instead are modified as part of a wide-ranging national political shift, accompanied by changes in regulatory policy that go well beyond the adoption of pro-defendant antitrust liability rules governing the conduct of dominant firms. Courts might impose additional limitations on antitrust enforcement, such as setting a higher bar for proving unlawful exclusion in concerted action cases or introducing additional, targeted impediments to private antitrust enforcement. Congress might restrict other types of regulation, for example, limiting environmental regulation or workplace safety rules. The federal government's role in national economic life could shrink markedly, perhaps reflected in broad tax relief and cutbacks in social welfare programs.

This outcome-a decisive rejection of the competition policy bargain by the Supreme Court in favor of business self-regulation and laissezfaire-appears unlikely because of the political response it would pro-

state enforcers, and private plaintiffs-makes it difficult to change the law through nonenforcement. Legislative change is not common in the antitrust field and, in the U.S. system, it is difficult to engineer. 
voke. ${ }^{177}$ After the late 2008 financial crisis and the results of the 2008 election, it is hard to see Congress and the Executive Branch accepting that result. A hypothetical example suggests how the political system could prevent the demise of the competition policy bargain.

Suppose that the Federal Trade Commission decided against Intel in the high-profile monopolization case it filed in late 2009, ${ }^{178}$ and the Supreme Court reversed that decision after an appellate review. Suppose further that the Court, building on recent decisions such as Trinko, wrote a broad and aggressively non-interventionist decision in favor of Intel-rejecting a reasonableness standard and adopting in its place a test that places a thumb on the scales to favor defendants (such as the disproportionate effects or no economic sense test) - and defended its decision with a strong endorsement of the six economic arguments against monopolization enforcement set forth in Part II.B. ${ }^{179}$ By doing so, the Court would make non-price exclusionary conduct cases as difficult to prove in the lower courts as predatory pricing is today.

Such a decision could fuel a political controversy both within and outside the antitrust world. The extent to which it would do so depends in part on internal factors, such as the breadth of the decision and its rationale, the extent to which the Court is split, and the vehemence of any dissent. Its political salience would also depend on external factors, particularly whether political actors opposed to the outcome can convincingly tie the hypothetical decision to others in order to frame the Court as coddling monopolists and looking out for the narrow interests

\footnotetext{
${ }^{177}$ In the wake of the Supreme Court's decision in Leegin Creative Leather Products, Inc. $v$. PSKS, Inc., 551 U.S. 877 (2007), overturning the longstanding per se rule against resale price maintenance, one state (Maryland) has enacted legislation prohibiting the practice under state law and a congressional committee has held hearings on similar federal legislation. See generally Michael A. Lindsay, State Resale Price Maintenance Laws After Leegin, ANTITrust SOURCE, Oct. 2009, http://www.abanet.org/antitrust/at-source/09/10/Oct09Lindsay10-23f.pdf.

178 Intel Corp., FTC Docket No. 9341 (Dec. 16, 2009) (complaint), available at http:// www.ftc.gov/os/adjpro/d9341/091216intelcmpt.pdf. The complaint, brought under Section 5 of the Federal Trade Commission Act, frames a monopolization violation. The allegations include claims that Intel employed "penalties, rebates, lump-sum and other payments across multiple products, [and] differential pricing" to maintain its monopoly power in the market for central processing units, an integrated circuit chip often described as the "brains" of a computer system. Id. 55 . These allegations lie near the line separating price predation from other exclusionary conduct by monopolists, and so raise the tension between the legal standards governing the review of these types of exclusionary conduct by dominant firms discussed above in Part I.A.

${ }^{179}$ Assume, in addition, that the decision clearly governs cases brought under Sherman Act Section 2 and is not limited to cases brought under FTC Act Section 5. See, e.g., FTC v. Ind. Fed'n of Dentists, 476 U.S. 447 (1986) (upholding an FTC decision made pursuant to FTC Act Section 5 on the basis that the condemned practice violated the Sherman Act).
} 
of big business rather than the interests of consumers or the public as a whole. ${ }^{180}$

If the hypothetical pro-Intel decision did come to fruition and created such a debate, other governmental institutions might respond by undoing its result ${ }^{181}$ — with legislation overturning it, through aggressive enforcement of state competition laws governing the conduct of dominant firms, or, after the composition of the Court changes, with a new decision limiting or overruling the Court's modification of monopolization law. Récognizing this possibility, ${ }^{182}$ it would take an unusually self-confident and determined Court to provoke such a controversy on its own, ${ }^{183}$ without a strong political wind at its back. ${ }^{184}$

\footnotetext{
${ }^{180}$ For example, if the hypothetical Intel decision had been handed down during the same term that the Court struck down restrictions on political contributions by corporations under the First Amendment, it is possible to imagine the two decisions together leading to a broader national debate over whether large firms play a beneficial or harmful role in our economy and political life than either would generate alone.

${ }^{181}$ Cf. Barry Friedman, Benched: Why the Supreme Court Is Irrelevant, New Republic, Oct. 1, 2009, http://www.tnr.com/article/politics/benched ("Time and again throughout history, when the Court has run afoul of popular politics and the political branches, the justices have paid a price.").

182 Even if the Court is sympathetic to the non-interventionist approach to monopolization doctrine, it may fear a political backlash from an expansive decision and so find for Intel in an uncontroversial way (e.g., holding for Intel on narrow grounds, or deciding the case in Intel's favor on procedural or factual grounds that do not require modification to the substantive standards governing monopolization). On the other hand, the Court may discount the possibility of a political reaction on the ground that any such response would take time and the political environment could change before opposing political forces successfully mobilize to overcome legislative inertia.

${ }^{183}$ On the other hand, the current Supreme Court may be unusually self-confident and determined. "The current Court, the most conservative since 1937 . . has backtracked on the broad New Deal understanding of federal power to regulate interstate commerce and has invalidated federal statutes with something approaching abandon. ..." Richard Posner, 1937, 2010, New Republic, Feb. 17, 2010, http://www.tnr.com/article/politics/19372010. But cf. Barry Friedman \& Dahlia Lithwick, Speeding Locomotive: Did the Roberts Court Misjudge the Public Mood on Campaign Finance Reform? SLATE, Jan. 25, 2010, http://www. slate.com/id/2242557/ (until a 2010 decision on the constitutionality of campaign finance reform, the Roberts Court did "a remarkable job of conforming its behavior to the prevailing public mood, resisting the impulse to go too far"). The Court's upcoming decision in American Needle, Inc. v. National Football League, 538 F.3d 736 (7th Cir. 2008), cert. granted, 129 S. Ct. 2859 (June 29, 2009)) may provide a window into its willingness to pursue an aggressive non-interventionist approach to antitrust in the current political environment.

184 The Trinko decision was handed down when the other branches of government, particularly the Executive Branch, were substantially more sympathetic to the non-interventionist perspective than they appear today. Even then, the Court did not accept the government's invitation to adopt the no economic sense test. See Brief of the United States and Federal Trade Commission as Amicus Curiae Supporting Petitioners, Verizon Commc'ns Inc. v. Law Offices of Curtis V. Trinko, LLP, 540 U.S. 398 (2004), available at http://www.justice.gov/atr/cases/f201000/201048.htm. If, in a new monopolization matter like the hypothetical Intel case, the Court nevertheless issues an expansive non-interventionist decision, and the political reaction does not weaken or overturn its holding
} 
If the courts endorse the non-interventionist arguments on monopolization standards, it is more realistic to suppose that such decisions would be framed as fine-tuning antitrust rules to better advance the goals of competition policy, not as questioning whether the benefits of antitrust enforcement exceed the costs. They would be presented as similar in spirit to the modifications to other antitrust rules associated with the success of the Chicago School, not as subverting the competition policy bargain. That is, judicial opinions accepting non-interventionist proposals to modify monopolization doctrine would likely present the change in standards as a reform that advances competition policy goals as those goals have been understood since the 1980s.

Even in this more limited form, the non-interventionist effort to raise the burden for plaintiffs seeking to demonstrate monopolization by exclusionary conduct faces hurdles. The prospects for success of a renewed non-interventionist bid for reform of antitrust rules are less today than they were three decades ago, when Chicago critiques led to thoroughgoing modifications of antitrust doctrines without overthrowing the political bargain, for three reasons.

First, during the 1980s, a bipartisan consensus, reflected in all three branches of the federal government, favored some sort of economic deregulation and antitrust reform. By contrast, there is no bipartisan consensus today that antitrust rules generally, or monopolization rules in particular, are overly restrictive or that they undermine economic goals in the pursuit of social and political goals. Second, the economic arguments in favor of reform of monopolization rules have been strongly (and, in my view, persuasively) countered by economic arguments in favor of preserving current rules governing non-price exclusionary conduct by dominant firms. ${ }^{185}$ Finally, among the three branches of the federal government, only the judiciary now seems inclined toward the noninterventionist position on monopolization, ${ }^{186}$ and its makeup may be-

(contrary to what I have supposed), an emboldened Court and its allies in other branches of government might be expected to take further steps to dismantle the post-New Deal regulatory state, potentially upsetting the competition policy bargain and replacing it with a laissez-faire system to govern economic affairs.

185 See discussion supra Part I.B.

186 The Supreme Court majority that decided Trinko appeared sympathetic to the noninterventionist critique, and recent changes in the composition of the Court are unlikely to shift its antitrust jurisprudence. On the role of conservative judicial appointments in securing and preserving the success of antitrust's Chicago School revolution, see William E. Kovacic, Reagan's Judicial Appointees and Antitrust in the 1990s, 60 FordHAM L. REv. 49 (1991). With respect to the rest of the government, the rejection of the political challenge to traditional monopolization standards, combined with the recent setback to the broad political movement to reverse the New Deal in the financial crisis and 2008 elections, have likely placed the advocates of non-interventionist antitrust on the defensive. But cf. Daniel 
gin to change as the Obama administration moves forward with judicial appointments. Hence, even a proposal to revise monopolization standards conceived as extending the Chicago School reforms of antitrust doctrine to a previously untouched area may be too partisan to succeed today. ${ }^{187}$

For the above reasons, I am skeptical about the current prospects for success of the non-interventionist effort to change monopolization standards. Courts are likely to leave the legal standard governing predatory conduct by a dominant firm largely unchanged, issuing to the extent possible narrow decisions that resolve monopolization cases based on their particular facts and procedural posture without reaching the substantive legal standard. ${ }^{188}$

A. Crane, Obama's Antitrust Agenda, Regulation, Fall 2009, at 16, 20 ("Obama's antitrust ambitions face significant obstacles in the courts, in Congress, in other regulatory agencies, and in the market itself.").

${ }^{187}$ Leegin, the 2007 decision discarding the per se rule against resale price maintenance, presented a different dynamic so provides a poor guide to how the Supreme Court might approach a monopolization matter like the hypothetical Intel case. Leegin Creative Leather Prods., Inc. v. PSKS, Inc., 551 U.S. 877 (2007). Against the background of previous resale price maintenance decisions, the holding in Leegin was not a surprise. The Court had narrowed the per se rule in several decisions since Continental T.V., Inc. v. GTE Sylvania Inc., 443 U.S. 36 (1977), when it set forth a new perspective on non-price vertical restraints that ultimately led it to question the per se rule regarding vertical agreements concerning price. In particular, the Court had raised the burden of proof for plaintiffs in Monsanto Co. v. Spray-Rite Service Corp., 465 U.S. 752 (1984) and Business Electronics Corp. v. Sharp Electronics Corp., 485 U.S. 717 (1988), and abandoned the per se rule for maximum resale price maintenance in State Oil Co. v. Khan, 522 U.S. 3 (1997). Moreover, most economists concerned about the anticompetitive potential of the practice had difficulty defending a per se prohibition as opposed to the rule of reason. See, e.g., Brief for William S. Comanor and Frederic M. Scherer as Amici Curiae Supporting Neither Party, Leegin Creative Leather Products, Inc. v. PSKS, Inc., 551 U.S. 877 (2007), available at http://www. antitrustinstitute.org/archives/files/aai-\%20Leegin,\%20Comanor\%20\&\%20Scherer\%20 amicus\%20brief_021820071955.pdf (preferring a structured rule of reason approach to the unstructured rule of reason proposed by other economists). Even with all this going for it, though, Leegin was adopted by only a narrow majority. The decision drew a passionate dissent, but many observers credited the heat to concern by the dissenters that the majority's willingness to overturn well-established precedent was a rehearsal for a future decision reversing Roe v. Wade, 410 U.S. 113 (1973). Alan Devlin, On the Ramifications of Leegin Creative Products, Inc. v. PSKS, Inc.: Are Tie-Ins Next? 56 Clev. ST. L. Rev. 387, 395-96 (2008), Einer Elhauge, Harvard, Not Chicago: Which Antitrust School Drives Recent Supreme Court Decisions?, Competition PoL'y INT'L, Autumn 2007, at 59, 66; Andrew I. Gavil, Antitrust Bookends: The 2006 Supreme Court Term in Historical Context, ANTITRUST, Fall 2007, at 21, 24. Moreover, the Leegin dissent defended the per se rule on the basis of stare decisis, not on the merits.

188 The Supreme Court could conceivably reject the non-interventionist proposals explicitly and reaffirm a reasonableness standard on grounds of the economic counter-arguments. In theory, it could even adopt antitrust reforms advocated by consumer interests, but that outcome is highly improbable for the current Court. 
Three future developments could make the success of the non-interventionist proposals on monopolization more likely. First, in the economic policy arena, it is possible that new economic thinking or empirical studies would strengthen the economic arguments for the non-interventionist position on monopolization doctrine, making the argument for revising the standard to the benefit of dominant firm defendants more convincing. ${ }^{189}$ Second, it is possible that the federal enforcement agencies will bring monopolization cases against multiple large and well-known firms and those companies will follow Microsoft's lead in challenging publicly the legitimacy of antitrust enforcement. ${ }^{190}$ If such an effort changes the political dynamic in Congress, it could embolden the Supreme Court to push monopolization law specifically and antitrust generally in a non-interventionist direction.

Finally, it is possible that the larger non-interventionist domestic policy agenda targeting governmental interference with the free market will return to prominence in domestic economic policy debates. ${ }^{191}$ That agenda continues to have strong advocates, particularly within the national Republican Party. ${ }^{192}$ The success of a reinvigorated conservative political movement could bring about a renewed effort to discard the political bargain adopting competition in favor of laissez-faire, leading to changes in antitrust law that go beyond relaxation of the monopolization rules. The specific rules implementing the competition policy bargain will undoubtedly change, as the future brings disputes with new factual settings, different judges on the bench, and new economic in-

\footnotetext{
189 Of course, new studies could instead strengthen the economic counter-arguments.

190 Intel's initial response to the FTC complaint charged that the agency had not done a thorough investigation and argued that the remedies that the FTC sought were excessively restrictive, but did not question the legitimacy of monopolization enforcement. Press Release, Intel Comments on FTC Suit (Dec. 16, 2009), available at http://www.intel. com/pressroom/archive/releases/2009/20091216corp.htm. Intel's General Counsel, A. Douglas Melamed, is an experienced antitrust lawyer who served as Principal Deputy Assistant Attorney General for Antitrust in the Clinton administration, where he helped direct the government's case against Microsoft.

${ }^{191}$ At times that agenda is tied rhetorically to concerns about the long-run sustainability of public sector fiscal deficits given the projected growth of health care and Social Security spending, but the two issues are logically distinct. The deficit grew substantially during the two modern administrations most sympathetic to the non-interventionist position (Reagan and G.W. Bush). Moreover, fiscal problems can be addressed by raising revenues as well as reducing spending, and lower spending need not be accompanied by less regulation.

${ }^{192}$ Cf. Kim Phillips-Fein, Right On, The NATION, Sept. 28, 2009, available at http://www. thenation.com/doc/20090928/phillips-fein ("[D]espite the financial crisis of the past year, the faith in laissez-faire that conservatives promoted throughout the postwar period continues to exercise a deep hold on American politics.").
} 
sights from the academy. But without a broad political mobilization by non-interventionists, the political bargain itself seems, at least for the moment, secure. 